\title{
Review \\ Nanomedicine to Overcome Multidrug Resistance Mechanisms in Colon and Pancreatic Cancer: Recent Progress
}

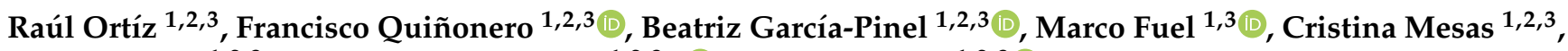 \\ Laura Cabeza ${ }^{1,2,3}$, Consolación Melguizo 1,2,3,*(D) and Jose Prados 1,2,3 (D) \\ 1 Institute of Biopathology and Regenerative Medicine (IBIMER), Center of Biomedical Research (CIBM), \\ University of Granada, 18100 Granada, Spain; roquesa@ugr.es (R.O.); fjquinonero@ugr.es (F.Q.); \\ beatrizgarnel@ugr.es (B.G.-P.); marcofh@correo.ugr.es (M.F.); cristinam@correo.ugr.es (C.M.); \\ lautea@ugr.es (L.C.); jcprados@ugr.es (J.P.) \\ 2 Department of Anatomy and Embriology, Faculty of Medicine, University of Granada, 18071 Granada, Spain \\ 3 Instituto Biosanitario de Granada (ibs.GRANADA), 18014 Granada, Spain \\ * Correspondence: melguizo@ugr.es; Tel.: +34-958-243535
}

check for updates

Citation: Ortíz, R.; Quiñonero, F.; García-Pinel, B.; Fuel, M.; Mesas, C.; Cabeza, L.; Melguizo, C.; Prados, J.

Nanomedicine to Overcome

Multidrug Resistance Mechanisms in Colon and Pancreatic Cancer: Recent Progress. Cancers 2021, 13, 2058.

https: / / doi.org/

10.3390/cancers13092058

Academic Editor: Clare Hoskins

Received: 27 March 2021

Accepted: 22 April 2021

Published: 24 April 2021

Publisher's Note: MDPI stays neutral with regard to jurisdictional claims in published maps and institutional affiliations.

Copyright: (C) 2021 by the authors. Licensee MDPI, Basel, Switzerland. This article is an open access article distributed under the terms and conditions of the Creative Commons Attribution (CC BY) license (https:/ / creativecommons.org/licenses/by/ $4.0 /)$.
Simple Summary: The cellular mechanisms of drug resistance prevent the correct efficacy of the therapies used in various types of cancer and nanotechnology has been postulated as a possible alternative to avoid them. This review focuses on describing the different mechanisms of drug resistance and dis-covering which nanotechnology-based therapies have been used in recent years to evade them in colon (CRC) and pancreatic cancer (PAC). Here we summarize the use of different types of nanotechnology (mainly nanoparticles) that have shown efficacy in vitro and in vivo in preclinical phases, allowing future in-depth research in CRC and PAC and its translation to future clinical trials.

Abstract: The development of drug resistance is one of the main causes of cancer treatment failure. This phenomenon occurs very frequently in different types of cancer, including colon and pancreatic cancers. However, the underlying molecular mechanisms are not fully understood. In recent years, nanomedicine has improved the delivery and efficacy of drugs, and has decreased their side effects. In addition, it has allowed to design drugs capable of avoiding certain resistance mechanisms of tumors. In this article, we review the main resistance mechanisms in colon and pancreatic cancers, along with the most relevant strategies offered by nanodrugs to overcome this obstacle. These strategies include the inhibition of efflux pumps, the use of specific targets, the development of nanomedicines affecting the environment of cancer-specific tissues, the modulation of DNA repair mechanisms or RNA (miRNA), and specific approaches to damage cancer stem cells, among others. This review aims to illustrate how advanced nanoformulations, including polymeric conjugates, micelles, dendrimers, liposomes, metallic and carbon-based nanoparticles, are allowing to overcome one of the main limitations in the treatment of colon and pancreatic cancers. The future development of nanomedicine opens new horizons for cancer treatment.

Keywords: drug resistance; colon cancer; pancreatic cancer; nanomedicine; cancer stem cells; PARP; miRNA; tumor microenvironment

\section{Introduction}

According to the latest epidemiological data, colorectal cancer (CRC) and pancreatic cancer (pancreatic adenocarcinoma or PAC) rank third and eleventh in cancer incidence worldwide, respectively. In terms of cancer mortality, they are the second and seventh leading causes, respectively. Despite its low incidence, PAC has the highest mortality rate of all cancers, with a 5-year survival rate of only $9 \%[1,2]$. On the other hand, CRC has a better prognosis in the initial stages of the disease, but in stage IV (i.e., metastatic) its mortality is also very high, with 5-year survival rates of only $13 \%$ [3]. In both PAC and 
stage IV CRC, current therapies only result in a slight increase in survival, mainly due to the phenomenon of drug-resistance.

Drug-resistance can be classified into innate or acquired (generated after treatment) [4]. Innate resistance usually results from pre-existing mutations in genes involved in cell growth or apoptosis [5]. For instance, the $p 53$ mutation abolishes the function of this protein, facilitating resistance to standard medications used in colon and pancreatic tumors, such as gemcitabine (GEM) (antimetabolites), doxorubicin (DOX) (anthracyclines), or cetuximab (EGFR-inhibitor) [6]. Genes involved in DNA repair systems (e.g., MMR) may be altered in these tumors [7]. These systems are responsible for failure to standard neoadjuvant chemotherapy with 5-fluorouracil (5-FU)/oxaliplatin (OXA) and 5-FU-based adjuvant chemotherapy [8]. Another source of innate resistance is the activation of cellular pathways involved in the elimination of toxic elements or in damage prevention. These pathways can be exploited by tumor cells to protect themselves from anti-tumor drugs [5]. Examples of these are the transporter pumps, such as the ATP binding cassette (ABC) family members, including MDR1 or P-glycoprotein-P-GP- (ABCB1), Multidrug ResistanceAssociated Protein 1 (MRP1) and Multidrug Resistance-Associated Protein 3 (MRP3) or Breast Cancer Resistance Protein (BCRP), which promote drug transport outside the cell in tumor pathology [9]. These existing pathways also include DNA repair enzymes such as poly(ADP-ribose) polymerase-1 (PARP-1), which allows cells to survive the DNA damage caused by both intrinsic and extrinsic factors, thus promoting drug resistance [10]. PARP-1 inhibition has been linked to the better response to therapy in various cancers, including PAC [11]. Finally, another source of innate resistance lies in the heterogeneity of the tumor, which may contain pre-existing cell subpopulations insensitive to treatment, including cancer stem cells (CSCs). Numerous trials have demonstrated the importance of CSCs in tumor resistance, since these cells are selected after chemo and radiotherapy [12], and may be resistant even to novel therapies, such as immunotherapy.

The resistance developed after antitumor treatment is known as acquired resistance and causes a gradual reduction of the anticancer efficacy of drugs. This resistance may result from the development of new mutations (which may affect new proto-oncogenes or modify treatment targets) or from alterations in the tumor microenvironment (TME) during treatment, leading to decreased antitumor efficacy of drugs. An example of modification of the treatment targets are mutations of the EGFR ectodomain, which have been shown to generate secondary resistance to anti-EGFR monoclonal antibodies (mAbs) (i.e., rituximab) in CRC $[13,14]$. Regarding TME-related acquired resistance, the TME promotes the survival and migration of cancer cells, conferring resistance to chemo, radio and immunotherapy treatments [15]. In sum, resistance phenomena involve complex and diverse resistance mechanisms that can occur simultaneously during tumor development and treatment. Therefore, it is essential to search for new therapeutic alternatives to overcome these mechanisms.

Nanomedicine is based on the use of nanomaterials, taking advantage of their different physicochemical properties to develop innovative applications in the field of medicine. The use of these materials has allowed significant improvements in antitumor treatment through the generation of nanoparticles (NPs) capable of transporting and releasing the drug in tumor cells more efficiently. In addition, NPs can be conjugated with different ligands on their surface to specifically damage tumor cells and reduce drug toxicity in healthy tissues [16]. Remarkable advantages of these molecules include their ability to passively accumulate in tumors via enhanced permeability and retention (EPR) effect, which results from increased disorganization of the vasculature and impaired lymphatic drainage of tumors, and their stability in blood due to improvements such as pegylation [17]. In this review, we will examine the different drug-resistance mechanisms of tumours and how the use of nanomedicine and, specifically, NPs can improve the treatment of CRC and PAC. 


\section{Increased Efflux of Drugs}

\subsection{Efflux Pump P-Glycoprotein and Drug Resistance}

One of the most relevant resistance mechanisms of cancer cells is P-GP, a membrane protein which pumps out the drugs from the inside of cells to the extracellular space, reducing their therapeutic effect [18]. This protein, also known as ATP-binding cassette subfamily B member 1 (ABCB1) or ABC transporters, comprises a superfamily of efflux pump proteins with different members that may be involved in the MDR phenotype of tumor cells. In addition to P-GP, other members from this superfamily play an important role in the MRD phenotype in CRC and PAC, such as MDR-associated proteins (MRPs/ABCCs) and breast cancer resistance protein (BCRP/ABCG2) [9,19] and MDR1 [20,21]. P-GP is a $170 \mathrm{kD}$ protein normally present in a variety of cells of the digestive system (e.g., common bile duct of the liver and pancreatic ducts), being highly expressed in the apical surface of epithelial cells [20]. However, the overexpression of P-GP in cancer cells is usually associated with a low therapeutic efficacy [22-27] especially in CRC. In this context, many nanoformulations have been designed to overcome the P-GP-mediated MDR phenotype in CRC and PAC (Table 1).

Table 1. Nanoformulations used to overcome the MDR phenotype mediated by efflux pumps in colorectal and pancreatic cancers.

\begin{tabular}{|c|c|c|c|c|c|}
\hline Nanoformulation & Drug/Cargo & Efflux pump & $\mathrm{CRC} / \mathrm{PC}$ & Mechanism to overcome MDR & Ref. \\
\hline $\begin{array}{l}\text { Gold nanorod coated with three } \\
\text { layers: } \mathrm{mSiO}_{2}, \text { PHIS and TPGS }\end{array}$ & DOX & P-GP & CRC & $\begin{array}{l}\text { PHIS to escape the endocytic } \\
\text { pathway and TPGS to inhibit P-GP }\end{array}$ & [28] \\
\hline Liposomes loaded with ACF & DOX & P-GP & CRC & $\begin{array}{c}\text { downregulation of P-GP in hypoxic } \\
\text { environment }\end{array}$ & [29] \\
\hline $\begin{array}{c}\text { Hydrogel with PEG-coated gold } \\
\text { nanorods and TPGS-coated PTX } \\
\text { nanocrystals }\end{array}$ & PTX & P-GP & CRC & TPGS inhibits P-GP & [30] \\
\hline $\begin{array}{c}\text { Vitamin E } \\
\text { succinate-grafted-chitosan } \\
\text { oligosaccharide with RGD } \\
\text { and TPGS }\end{array}$ & BU & P-GP & CRC & TPGS and BU inhibits P-GP & [31] \\
\hline $\begin{array}{l}\text { Lignin NPs functionalized with } \\
\text { hyaluronic acid } \\
\text { transporting quercetin }\end{array}$ & IRI & P-GP & CRC & Quercetin inhibits P-GP & [32] \\
\hline $\begin{array}{l}\text { Nanovectors derived from } \\
\text { grapefruit lipids with the LA1 } \\
\text { aptamer and siRNA }\end{array}$ & DOX & P-GP & CRC & Downregulation of P-GP expression & [33] \\
\hline $\begin{array}{l}\text { Microbubbles transformable } \\
\text { into NPs for PDT and imaging }\end{array}$ & $\mathrm{CPT}$ & ABCG2 & CRC & Reduction of ABCG2 expression & [34] \\
\hline PEG-PLGA NPs & SN38 & ABCG2 & CRC & Reduced mRNA expression level & [35] \\
\hline Curcumin loaded in HP- $\beta-C D$ & DOX & P-GP & CRC & $\begin{array}{l}\text { Curcumin nanoformulation } \\
\text { overcomes DOX resistance }\end{array}$ & [36] \\
\hline $\begin{array}{c}\text { Polymeric NPs with PEG } \\
\text { and PEI }\end{array}$ & Ce6 & ABCG2 & PC & $\begin{array}{l}\text { NPs reduce the ABCG2 efflux } \\
\text { of } \mathrm{Ce} 6\end{array}$ & [37] \\
\hline pHPMA-b-pDMAEMA NPs & ODNs & P-GP & CRC & $\begin{array}{c}\text { Decreased P-GP expression by } \\
\text { modulation of NF- } \mathrm{B} \\
\text { signalling pathway }\end{array}$ & [38] \\
\hline $\begin{array}{l}\text { Poly (aspartic acid) with TAT } \\
\text { peptide and PEG }\end{array}$ & DOX & P-GP & CRC & $\begin{array}{l}\text { Inhibition of P-GP efflux activity by } \\
\text { size exclusion-effect }\end{array}$ & [39] \\
\hline Nanomicelles with SMA & PTX & P-GP & CRC & $\begin{array}{c}\text { Enhance of drug antitumor effect } \\
\text { with oral administration }\end{array}$ & [40] \\
\hline $\begin{array}{l}\text { Liposomes for PDT with } \\
\text { benzoporphyrin derivate }\end{array}$ & IRI & ABCG2 & PC & $\begin{array}{l}\text { Sinergy of PDT and IRI: PDT } \\
\text { reduces the efflux of ABCG2 }\end{array}$ & [41] \\
\hline $\begin{array}{l}\text { PLGA NPs functionalized with } \\
\text { Pluronic F127 and chitosan }\end{array}$ & $\mathrm{CPT}$ & P-GP & CRC & $\begin{array}{l}\text { Pluronic F127 and chitosan } \\
\text { downregulate MDR1 expression }\end{array}$ & [42] \\
\hline
\end{tabular}


Table 1. Cont.

\begin{tabular}{|c|c|c|c|c|c|}
\hline Nanoformulation & Drug/Cargo & Efflux pump & CRC/PC & Mechanism to overcome MDR & Ref. \\
\hline $\begin{array}{l}\text { Liposomes coated with } \\
\text { hyaluronic acid }\end{array}$ & $\begin{array}{l}\text { Imatinib } \\
\text { mesylate }\end{array}$ & P-GP & CRC & Nanosystem P-GP modulation & [43] \\
\hline Pegylated liposomes & $\begin{array}{c}\text { ASOs } \\
\text { and/or EPR }\end{array}$ & $\begin{array}{c}\text { MDR1, } \\
\text { MRP1, MRP2 }\end{array}$ & CRC & $\begin{array}{c}\text { Reduced expression of MDR1, } \\
\text { MRP1 and MRP2 }\end{array}$ & [44] \\
\hline $\begin{array}{l}\text { Hybrid lipid NPs with AL-HA } \\
\text { polymer }\end{array}$ & IRI & P-GP & CRC & $\begin{array}{l}\text { Disruption of ATPase activity and } \\
\text { reduction of MDR } 1 \text { gene expression }\end{array}$ & [45] \\
\hline $\begin{array}{l}\text { Inactive phenolato-titanium } \\
\text { (IV) complexes }\end{array}$ & - & P-GP & CRC & $\begin{array}{l}\text { Same toxicity in sensitive and } \\
\text { resistant tumor cells }\end{array}$ & [46] \\
\hline $\begin{array}{l}\text { Liposomes functionalized with } \\
\text { specific phage fusion proteins }\end{array}$ & DOX & P-GP & PC & $\begin{array}{l}\text { Same drug accumulation in tumor } \\
\text { cells in presence and absence } \\
\text { of verapamil }\end{array}$ & [47] \\
\hline Liposomes & NitDOX & P-GP, MRP1 & CRC & $\begin{array}{l}\text { Efflux activity reduction by } \\
\text { nitration of P-GP and MRP1 with } \\
\text { NO released by NitDOX }\end{array}$ & [48] \\
\hline Liposomes with PEG & PTX & P-GP & CRC & $\begin{array}{l}\text { Similar antitumor activity in vivo } \\
\text { between mice bearing resistant } \\
\text { tumor and non-resistant tumor }\end{array}$ & [49] \\
\hline $\begin{array}{l}\text { NPs of PEG-PLA functionalized } \\
\text { with K237 peptide }\end{array}$ & PTX & P-GP & CRC & $\begin{array}{l}\text { NPs target endothelial cells for } \\
\text { antiangiogenic and antitumor } \\
\text { activity in resistant tumors }\end{array}$ & [50] \\
\hline Pegylated liposomes & $\begin{array}{l}\text { ASOs and/or } \\
\text { EPR }\end{array}$ & $\begin{array}{c}\text { P-GP, } \\
\text { MRP1,MRP2 }\end{array}$ & CRC & $\begin{array}{l}\text { Similar antitumor activity in } \\
\text { resistant and non-resistant tumors }\end{array}$ & [51] \\
\hline PLGA NPs and liposomes & GEM & NS & PC & $\begin{array}{l}\text { Increase in GBC cytotoxicity in } \\
\text { resistant tumor cell lines }\end{array}$ & [52] \\
\hline Anionic liposomal NPs & DOX & P-GP & CRC & $\begin{array}{l}\text { Nanosystems change the amount of } \\
\text { P-GP lipid rafts and inhibit efflux } \\
\text { activity (glycine 185) }\end{array}$ & [53] \\
\hline $\begin{array}{l}\text { PRA nanodrug coated with } \\
\text { hyaluronic acid }\end{array}$ & - & P-GP & CRC & $\begin{array}{l}\text { Generation of holes in resistant cells } \\
\text { makes them more sensitive to DOX }\end{array}$ & [54] \\
\hline
\end{tabular}

Mesoporous silica (mSiO2); $\mathrm{pH}$ responsive polyhistidine (PHIS); acriflavine (ACF); hypoxia-inducible-factor- $1 \alpha$ (HIF- $1 \alpha)$; d- $\alpha$ tocopherol polyethylene glycol 1000 succinate (TPGS); doxorubicin (DOX); P-glycoprotein (P-GP); colorectal cancer (CRC); pancreatic cancer (PAC); photothermal therapy (PTT); poly lactic-co-glycolic acid (PLGA); nanoparticles (NPs); verapamil (VER); polyethylene glycol (PEG); paclitaxel (PTX); arginine-glycine-aspartic acid (RGD); bufalin (BU); hydroxypropyl- $\beta$-cyclodextrin (HP- $\beta$-CD); polyethylenimine (PEI); chlorin e6 (Ce6); ATP-binding cassette subfamily G member 2 (ABCG2); NF- $\mathrm{kB}$ decoy oligodeoxynucleotides (ODNs); photodynamic therapy (PDT); poly[N-(2-hydroxypropyl)methacrylamide]-poly(N,N-dimethylaminoethylmethacrylate) (pHPMA-b-pDMAEMA); antisense oligonucleotides (ASOs); camptothecin (CPT); epirubicin (EPR); alendronic acid and hyaluronic acid (AL-HA); irinotecan (IRI); nitric oxide-releasing DOX (NitDOX); polyethyleneimine/all-trans retinoic acid conjugates (PRA); poly(styrene-co-maleic acid) (SMA); gemcitabine (GEM); not specified (NS).

Despite the fact many P-GP inhibitors have been developed (e.g., verapamil, tariquidar, 11C-laniquidar, natural alkaloids or herbal natural products) [55-59], most of them showed significant limitations (systemic toxicity, insolubility, short blood half-life or rapid metabolization) $[21,58,60,61]$. The use of nanoformulations could overcome these drawbacks (Figure 1A). Recently, bufalin (BU), an antitumor drug that blocks P-GP-mediated resistance in CRC [62], was associated with vitamin E succinate-grafted-chitosan oligosaccharide with RGD peptide (arginine-glycine-aspartic acid) and TPGS. Compared to free $\mathrm{BU}$, this combination showed improved antitumor activity (43\% tumor volume reduction), pharmacokinetic profile and toxicity in resistant-CRC (LoVo/ADR cells)-bearing nude mice [31]. Moreover, the nanoformulation alone (i.e., without P-GP inhibitors) can overcome the P-GP-mediated MDR. For instance, treatment of PANC-1, a PAC cell line that overexpresses P-GP with DOX-loaded liposomes modified with phage fusion proteins for specific targeting, showed similar drug accumulation in presence and absence of verapamil $[63,64]$. Accordingly, this nanoformulation avoided P-GP-mediated expulsion and increased cytotoxicity of DOX ( $\mathrm{IC}_{50}$ 10-fold lower) [47]. Pan, et al. [65] overcame MDR mediated by P-GP in HCT8/ADR resistant cells using a large nanoformulation consisting of DOX-loaded poly(aspartic acid) NPs functionalized with TAT peptide and PEG, which is not a substrate of the efflux pump. In other cases, multifunctional NPs that combine 
several strategies at the same time to overcome the MDR phenotype have been used. For example, DOX-loaded gold nanorods coated with mesoporous silica $\left(\mathrm{mSiO}_{2}\right)$ used in CRC photothermal therapy (PTT) and chemotherapy have been improved by using $\mathrm{pH}$-responsive polyhistidine (PHIS) and D- $\alpha$-tocopherol PEG 1000 succinate (TPGS) to induce endocytic pathway escape and to inhibit P-GP, respectively [28]. These nanorods showed excellent results in male athymic nude mice bearing SW620/Ad300 cells, achieving a significant reduction in tumor volume ( 3-fold) with low systemic toxicity. Interestingly, resistant CRC has also been treated with local PTT using gold nanorods coated with PEG and paclitaxel (PTX) nanocrystals coated with TPGS (all of them combined into a hydrogel). Promising results were obtained in the SW620/Ad300 cell line in vitro ( 178-fold decrease in the IC50 of PTX) and in male athymic nude mice bearing SW620/Ad300 tumors [30]. The use of phosphatidylserine (PS) lipid nanovesicles with encapsulated PTX showed a synergistic effect against the chemoresistant HCT15 cell line overexpressing the MDR1 gene product P-GP, both in vivo an in vitro. These NPs induced cell cycle arrest at G2/M phase, downregulated $k i-67, B c l-2$, and $C D 34$, upregulated caspase 3, reduced the systemic toxic effects of PTX and no inflammatory response was reported [66].
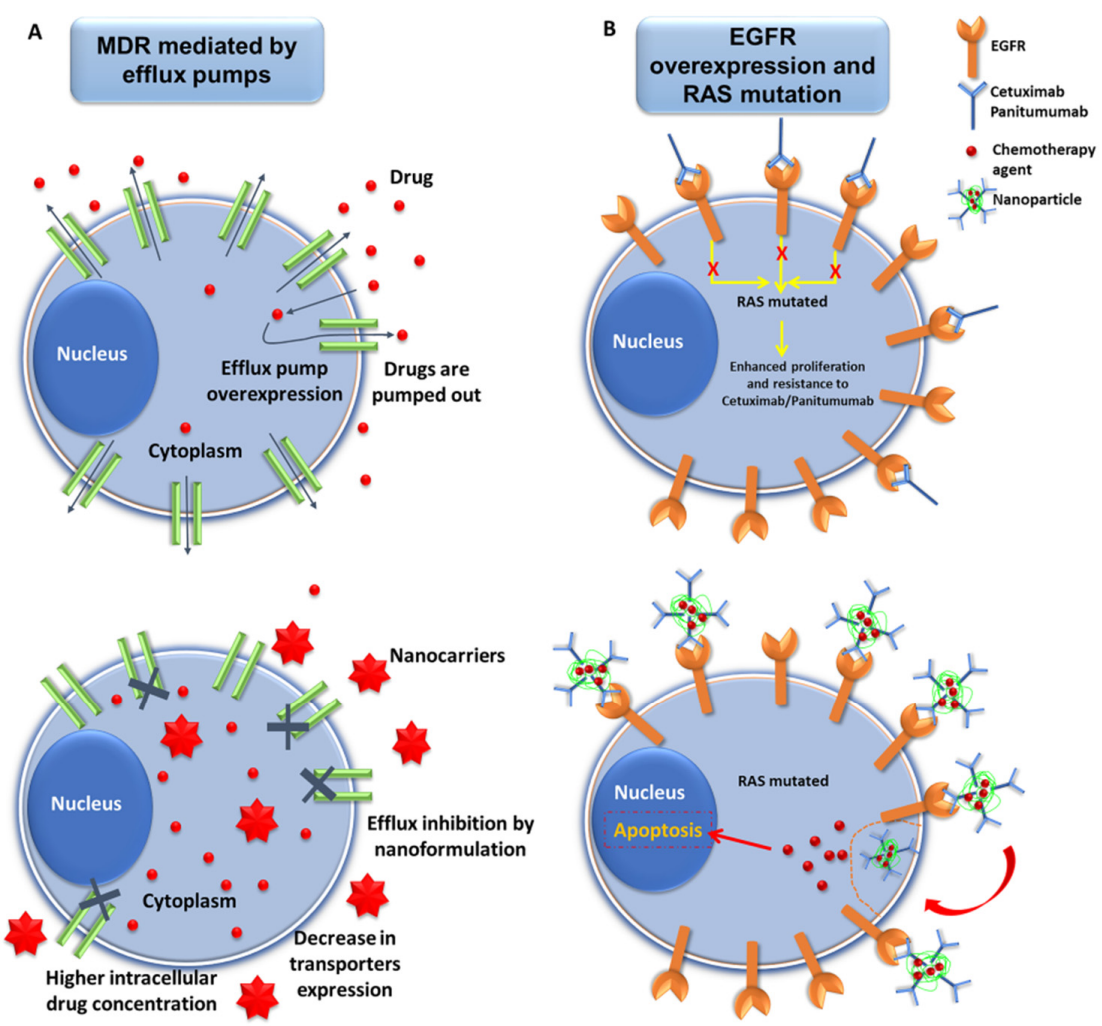

Figure 1. Representative scheme of nanomedicine strategies against drug resistance in pancreatic cancer. (A) Interactions of nanoformulations with MDR mechanism in pancreatic cancer (PAC) cells. Drugs carried by NPs may overcome MDR mechanisms of PAC cells mediated by efflux pumps via the inhibition of drug efflux, decrease in the expression of the transporter proteins, and increased accumulation of drug inside the tumor cells. (B) Exploiting the overexpression of EGFR to overcome resistance mediated by RAS mutations in PAC cells. PAC cells overexpress EGFR, which can be targeted by NPs conjugated with mAbs (Cetuximab/Panitumumab) (see below). This enables increased internalization of the chemotherapy drugs, thus leading to cellular apoptosis, even in RAS-mutated cancer cells.

\subsection{Other Efflux Pumps}

Breast cancer resistance protein (BCRP/ABCG2), also known as mitoxantrone resistance protein $(\mathrm{MXR})$ or placenta $\mathrm{ABC}$ protein $(\mathrm{ABC}-\mathrm{P})$, is a small member of the $\mathrm{ABC}$ 
superfamily ( 75 KDa) with a more limited number of substrates (e.g., amptothecin [CPT], tyrosine kinase inhibitors and methotrexate) and inhibitors (e.g, imatinib or poloxamines) compared to P-GP [67]. Although BRCP/ABCG2 is usually highly expressed in hematological cancers, it has also been found to be overexpressed in CRC and PAC [68,69]. In fact, 72\% of pancreatic cell lines from the Cancer Cell Line Encyclopedia (CCLE) overexpressed this protein [69]. Nanoformulations such as irinotecan-loaded liposomes with benzoporphyrin derivative for photodynamic therapy (PDT) were able to overcome ABCG2-mediated resistance, decreasing tumor volume from $70 \%$ to $25 \%$ in mice bearing pancreatic tumors [41]. PDT has also been used with polymeric NPs with PEG and polyethylenimine (PEI) in pancreatic cells with variable expression levels of ABCG2 (+AsPC-1 and -MIA PaCa-2 and induced +MIA PaCa-2), increasing the intracellular concentrations of the photosensitizer through reduction of its efflux by ABCG2 [37]. On the other hand, pegylated poly-lacticco-glycolic acid (PLGA) NPs with verapamil and SN38 (active form of CPT) showed no significant differences in drug cytotoxicity in HT29 CRC cells, but a significant decrease in ABCG2 mRNA expression (2.277-fold) in comparison with the free drug (4.793-fold) was observed [35]. In addition, microbubbles containing porphyrin/CPT-floxuridine for chemotherapy, PDT and imaging, generated NPs suitable for tumor therapy after exposure to ultrasound. This treatment significantly reduced the expression of ABCG2 in HT29 cells by increasing the concentration of CPT, inducing an in vivo growth inhibition $(90 \%)$ of the tumor without recurrence [70].

On the other hand, the MRP1/ABCC1 and MRP3/ABCC3 proteins, which have a similar molecular weight ( $190 \mathrm{KDa}$ ) and structure, contain a different n-terminal region in relation to P-GP [71-73]. Drug substrates of MRP1 and P-GP are similar except for taxanes, which are only P-GP substrates [73]. The spectrum of molecules transported by MRP3 is limited [74] In fact, MRP1 is the protein mostly involved in the therapeutic failure resulting from MDR [75]. Some nanoformulations have been designed to specifically overcome efflux pumps, including MRP. Nitric oxide-releasing DOX (NitDOX) was loaded in liposomes to treat HT29 cells resistant to DOX mediated by MRP1 and P-GP. Nitration of both proteins significantly reduced their activity [48]. In addition, pegylated liposomes loaded with epirubicin and antisense oligonucleotides (ASOs) against MDR1, MRP1 and MRP2 increased the antitumor activity of the drug in mice bearing CRC (CT26 cells), while administration of ASOs alone did not show significant differences between resistant and non-resistant tumors [51].

\section{Alteration of Drug Target}

Targeted therapy uses drugs that damage tumor cells and specific targets such as genes, proteins, or the environment of cancer-specific tissues, all of which contribute to cancer growth and survival. However, cancer cells can develop resistance by altering these pharmacological targets, either through genetic mutations or via changes in epigenetic gene expression [76].

\subsection{Epidermal Growth Factor Receptor (EGFR) Pathway}

The epidermal growth factor receptor (EGFR), also known as ErbB1 or HER1, is a transmembrane glycoprotein of the tyrosine kinase family with the epidermal growth factor as a ligand. Although present in the majority of cells, this protein is a target for cancer therapy because of its overexpression, amplification and mutation in a wide variety of solid tumors [5,77]. EGFR-targeting agents clinically used in malignancies include mAbs against the extracellular domain of the receptor, and small molecules (tyrosine kinase inhibitors). However, EGFR mutations, such as EGFRvIII, which is characterized by the loss of part of the extracellular ligand binding domain due to deletion of exon 2-7, may generate resistance to treatment $[78,79]$.

Although CRC and PAC rarely show EGFR mutations, both cancers overexpress this receptor and have been treated with cetuximab or panitumumab and erlotinib, respectively [80]. However, overexpression of EGFR does not imply dependence of cancer 
cells on this receptor for oncogenic signaling. In fact, KRAS-mutated cancer cells do not require EGFR activation. Therefore, this mutation predicts resistance to EGFR-targeted therapy [81-83]. As described by Van Emburgh, et al. [84], 60\% of patients with resistance to cetuximab or panitumumab showed the KRAS mutation. In this context, nanoformulations loading anticancer agents and $\mathrm{mAbs}$ have been developed, with the nanoconjugation design being a critical step for therapy (Figure 1B). For instance, Khan, et al. [85] used gold NPs associated with cetuximab against PAC cells. More recently, McDaid, et al. [86] used polymeric NPs loaded with camptothecin and conjugated with cetuximab against cetuximab-resistant PAC cells with mutated KRAS. This treatment produced a greater reduction in tumor growth than each of the drugs alone in mice, demonstrating the potential applicability of this therapeutic strategy. Functionalization of NPs with anti-EGFR antibodies was another solution to transport new non-water soluble anti-cancer compounds. Parvifloron D, isolated from a plant extract, is a hydrophobic drug with significant antitumor activity. Its conjugation with albumin NPs functionalized with anti-EGFR antibodies (erlotinib and cetuximab) made possible the treatment of PAC cells [87]. In CRC, gold NPs loaded with 5-FU and functionalized with cetuximab induced more apoptosis than the free drug in HCT-116 and HT-29 CRC cells [88]. These results were supported by those of Leve, et al. [89]) in HCT-116 CRC cells using similar nanoconjugates.

Finally, some peptides such as GE11 have been used to target the EGFR. GE11 conjugated with NPs loaded with GEM and olaparib was used against PAC with mutated BRCA2, obtaining favorable results both in vitro and in vivo [90]. Similarly, a significant increase in cytotoxicity was obtained using PLGA gelatin NPs functionalized with an EGFR-targeting peptide and loaded with GEM in an orthotopic PAC animal model [91]. As is the case with PAC, polyamino acid NPs with GE11 peptide have been used to transport evodiamine, an indolequinone alkaloid which is highly effective against CRC but with low solubility. This nanoformulation induced a significant increase in drug cytotoxicity in vivo, along with a drastic reduction of metastases and GFR, VEGF and MMP protein expression [92].

\subsection{Vascular Endothelial Growth Factor Pathway}

The vascular endothelial growth factor (VEGF), a promoter of tumor angiogenesis and, consequently, and inductor of metastasis and proliferation, has been used as a target to reduce tumor growth. The use of NPs may improve the antiangiogenic effect of treatments. For instance, Leng, et al. [93] obtained excellent in vitro and in vivo results in CRC through the functionalization of calcium phosphate NPs loaded with 5-fluorocystone and with genetic sequences that inhibit the expression of VEGF (Lovo cell line). Lee, et al. [94] exposed a system of theragnostic nanoplatforms functionalized with small interfering RNA (siRNA) which located and blocked the cells that produce this factor in large quantities. The incorporation of campothecin (SN-38) to these NPs allowed a selective effect in CRC cells.

\section{Enhanced DNA Damage Repair}

The development of small mutations in essential genes involved in cellular regulation, such as tumor suppressor genes (e.g., p53) and chromosomal instability are among the primary reasons underlying the formation of new tumors [95]. Genomic stability is maintained by highly efficient replication and damage repair mechanisms [96]. However, these mechanisms may be related to drug resistance. In fact, the inhibition of DNA repair pathways has also been advocated to increase the efficacy of treatment in various types of cancer. In this context, the PARP family and MMR, involved in the repair of DNA damage, have been explored to avoid MDR using nanotechnology.

\subsection{PARP Related Mechanisms}

One of the first events produced after DNA damage is the recruitment of the PARP1 enzyme, a protein capable of binding poly-ADP ribose to different proteins, including itself. This binding allows the recruitment and stabilization of protein complexes involved in 
DNA damage repair through different pathways, namely single-strand break repair (SSBR), nucleotide excision repair (NER) and base excision repair (BER). Furthermore, PARP is involved in the repair of double-strand breaks in DNA via homologous and non-homologous end joining (NHEJ), and also participates in the modulation of the structure of chromatin, which implies a great influence on the regulation of important cellular processes [97]. The relevance of PARP1 in all these processes has prompted the development of several inhibitors to avoid efficient repair of DNA damage which, together with mutations produced in other repair pathways, can prevent resistance to pharmacological treatment.

The use of PARP1 inhibitors associated with NPs has been assayed in some cancers such as hepatocellular carcinoma (arsenite and DOX) [98], prostate cancer (nanoolaparib) [99], ovarian cancer (NPs loaded with olaparib and cisplatin) [100] and, especially, breast cancer. Regarding the last group, the use of nanoliposomes loaded with a PARP inhibitor (talazoparib) in BRCA-negative breast cancer [101] and the use of talazoparibloaded solid lipid NPs (LPNs) in triple negative breast cancer [102] demonstrated enhanced therapeutic efficacy (Figure 2). Moreover, PAC has also been associated with BRCA1/2 mutations and there are ongoing early-phase studies using PARP1 inhibitors in this cancer. In fact, talazoparib was studied in patients with advanced PAC [103]. Recently, NPs loaded with GEM and Olaparib were used to specifically target BRCA2-negative cells that overexpress EGFR. Encapsulation and functionalization of NPs allowed to increase the half-life in blood of drugs and their accumulation within the tumor tissue [90]. The use of PARP inhibitors with NPs in CRC has not been exploited. In fact, early-phase clinical studies using PARP1 inhibitors (specifically Olaparib) in metastatic CRC showed no significant efficacy. Authors leave open the possibility of using PARP inhibitors together with chemoor radiotherapy with the aim to improve the effectiveness of treatment [104]. It is still necessary to determine the influence of PARP on drug resistance in CRC, in addition to the development of new NPs that allow an efficient transport of new inhibitors. Therefore, further studies are required in this type of cancer.

A

B

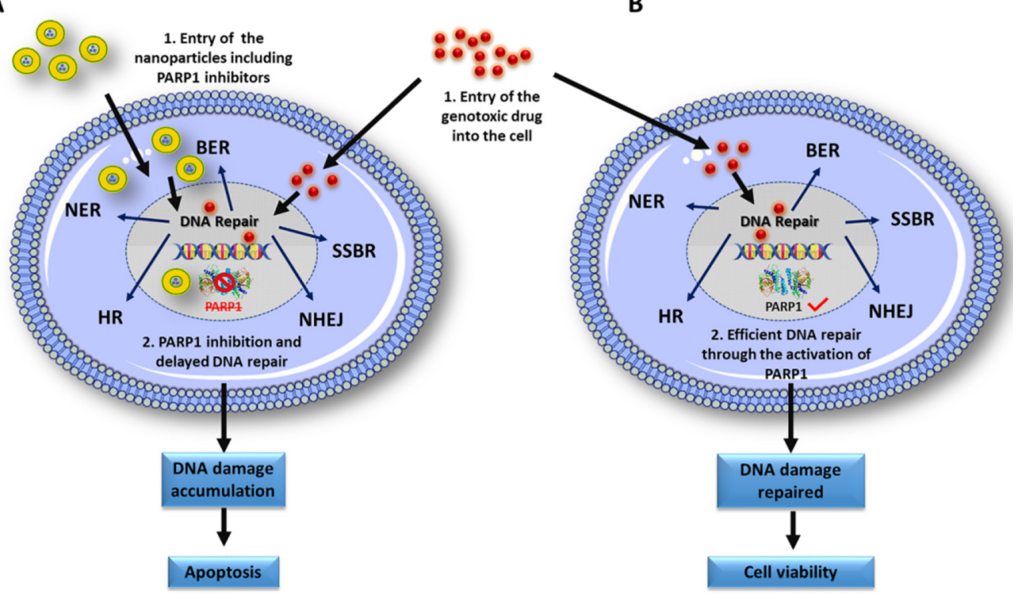

Figure 2. Nanoformulations to fight against drug resistance induced by PARP1. PARP1 modulates DNA damage repair by single-chain (SSBR, BER and NER) and double-chain (HR and NHEJ) repair pathways. PARP inhibitors are used to avoid drug resistance by limiting PARP1 functions in the different DNA repair pathways in which this protein is involved and therefore nanoformulations containing PARP inhibitors have been designed for different types of cancer. (A) The simultaneous entry of nanoparticles containing PARP1 inhibitors together with the genotoxic drug causes the inactivation of PARP1, necessary for the efficient repair of DNA damage through all the routes in which it is involved. This causes that the damages produced by the genotoxic agent in the DNA are not repairable, inducing cellular apoptosis.; (B) Entry of the genotoxic agent into the cell produces easily repairable DNA damage through DNA repair pathways where PARP1 acts as an important effector, leading to cell survival. Abbreviations: homologous recombination (HR). 


\subsection{MMR Based Mechanisms}

The MMR system is responsible for repairing errors generated by DNA polymerases during the process of DNA replication and recombination. Proteins such as MLH1, MHS2, MHS6 and PMS2 interact as heterodimers in this process in order to recognize mismatches and insertion-deletion errors, eliminating the erroneous DNA fragment and resynthesizing the correct strand [105]. The MMR system repairs damage caused by both endogenous and exogenous factors (ionizing and UV radiation, chemical agents, toxins, chemo/radiotherapy, or environmental stress) [106]. It has been demonstrated that mutations of certain genes involved in these pathways (e.g., BRCA1, BRCA2, PALB2 and MSH2) lead to lower DNA repair in the tumor, increasing the efficiency of drugs and the survival of patients [107].

The MMR system has been associated with CRC. For instance, epigenetic changes of germline MMR genes (MSH2, MLH1, MSH6 and PSM2) have been correlated with Lynch syndrome (1/35 cases of CRC) [108]. In addition, CRC cell lines with MLH1 mutations showed a higher sensitivity to treatment with irinotecan, increasing DNA damage. The addition of PARP inhibitors increases the damage produced, leading to extensive apoptosis in the population of tumor cells [109]. The use of iron particles reduced the expression of two MMR genes (PMS1 and MSH2) in lung cancer, inducing defective DNA repair. However, the employment of nanotechnology to inhibit the MMR pathways is anecdotal in tumor pathology, including CRC [110]. Although the mechanisms of DNA damage repair based on MMR and other pathways have been extensively studied, further research on new inhibitors is needed to increase the sensitivity of chemo/radiotherapy in cancer, in addition to the development of NPs that allow the correct function and efficient distribution of these inhibitors.

\section{Pro- and Anti-Apoptotic Genes: Evasion and Overexpression}

Cancer cells develop strategies to decrease the activity of pro-apoptotic proteins or increase the activity of anti-apoptotic proteins [111], avoiding programmed cell death and generating resistance. NPs have been used with the aim to modulate the Bcl-2 protein family, which includes both anti-apoptotic (e.g., Bcl-2, Bcl-XL, Mcl-1) and pro-apoptotic members (e.g., BAX, Bak), among others [112]. Metal NPs such as silver NPs (AgNPs) have been reported to cause downregulation of anti-apoptotic genes ( $B c l-2$ and $B c l-X L)$, and upregulation of pro-apoptotic genes (Bax, Bad and Bak) in HCT116 and CaCo2 CRC cells, and in HT-29 lung cancer cells [113-117]. In addition, these NPs led to an increased expression of the $p 53$ and p21 genes and to higher levels of caspase 3, inducing p53mediated apoptosis $[114,117]$. A similar effect was observed in PANC-1 cells with the use of AgNPs, which decreased the expression of Bcl-2 while increased that of Bax, $p 53$ and autophagy proteins (RP-1, RIP-3, MLKL and LC3-II) [118]. In addition, a nanoemulsion system incorporating lycopene (LP) and gold NPs (AN) reduced proliferation in HT-29 cells mediated by a significant decrease in the expression of procaspases $8,3,9$, PARP-1 and Bcl-2, whereas the Bax expression increased [119]. Magnetic gold NPs loaded with siRNA have been used to decrease the expression of Bag-1, another anti-apoptotic gene highly expressed in colon cancer cells (LoVo cells) [120]. Furthermore, copper oxide NPs (CuO-NPs) inhibited the proliferation of HT-29 and SW620 cancer cells by decreasing the expression of Bcl-2 and Bcl-xL [121]. Finally, copper cysteamine (Cu-cy) NPs activated by X-rays have been used against SW620 CRC cells, producing apoptosis by autophagy due to the increased expression of Bax, LC 3B-II and p62, and the decreased expression of Bcl-2 [122].

On the other hand, certain toxic anticancer agents that influence the expression of pro-apoptotic or anti-apoptotic proteins were conjugated with NPs to tackle this resistance mechanism. Accordingly, arsenic trioxide encapsulated in an ethylene glycol/poly D,Llactide copolymer and conjugated with anti-CD44v6 led to decrease Bcl2 and increased caspase 3 levels in PANC-1 PAC cells [123]. In Caco2 and HeLa cancer cells, orthorhombic tungsten oxide NPs decreased cell viability by $65 \%$ and $73 \%$, respectively, by reducing 
the expression of $B c l-2$ and $M M P 7$ [124]. Motawi, et al. [125] reported that cromolyn chitosan NPs led to a decreased expression of Bcl-2, NF-k $\beta$ and an increased expression of Bax in dimethylhydrazine-induced CRC in rats. Finally, some natural products from marine or plant resources associated with NPs can also affect the expression of apoptotic proteins. Fucoxanthin (FUCO), a marine carotenoid, in combination with nanogels (NG) of chitosan (CS) and glycolipids (GL), reduced the expression of Bcl-2 and increased the activity of Bax, ROS and caspase 3 in Caco-2 cells [126]. Gambogic acid, another natural compound extracted from gamboge, conjugated with magnetic NPs (MN-Fe304), induced the modulation of Bcl-2, iBax, and caspases 9 and 3 in Capan-1 PAC [127]. In addition, a dendrosomal curcumin nanoformulation increased the expression of $B A X, N o x a$ and $p 21$ and decreased that of $B c l-2$ in $p 53$-mutant SW480 colon cancer cells. Moreover, curcuminloaded magnetic NP formulations were tested in HPAF-II and PANC-1 cells, decreasing cell proliferation, both in in vitro and in vivo models. Also, these NPs reduced the tumor volume and downregulated $B c l-X L, M c l-1, P C N A, M U C 1$ and collagen I, and upregulated the expression of $\beta$-catenin [128].

\section{RNAs in Drug Resistance}

In recent years, the importance of the non-coding portion of the genome in the development of diseases has been recognized. Non-coding RNA (ncRNA) comprises different members such as piRNAs, snoRNAs or lincRNAs. However, two ncRNAs, namely lncRNA and miRNA, are known to have the highest incidence in pathologies. Dysregulation of their expression levels can cause drug resistance in various types of cancer [129]. LncRNAs play an important role in regulating mRNA stability, in RNA splicing and in genetic regulation of miRNAs. In PAC, various lncRNAs have been linked to epithelial mesenchymal transition (EMT) processes, regulation of CSCs, cellular hypoxia, modulation of epigenetic modifications, chemo-resistance, and regulation of the tumor microenvironment $[130,131]$. In CRC, deregulation of the XIST IncRNA decreased DOX resistance through its influence on the regulation of miR-124 and SGK1 protein expression [131]. Other lncRNAs such as UCA1 and CACS15 confer resistance to 5-FU and OXA, respectively, through the regulation of relevant miRNAs and genes involved in damage resistance pathways (miR-204-5p, miR-145 and the ABCC1 protein) [132,133]. On the other hand, miRNAs, the most studied ncRNAs, are involved in the regulation of approximately $30 \%$ of human genes (cell cycle regulation, proliferation, and stress tolerance), including those related to drug resistance in different cancers such as breast, ovarian, colorectal, pancreatic and gastric, among others [134]. Specifically, the deregulation of 16 miRNAs has been described in CRC, and the analysis of patients with MDR tumors determined that some of these miRNAs were overexpressed in exosomes obtained from the blood serum of the said patients. Nanotechnology and miRNAs may be the basis to develop new therapeutic options to improve cancer prognosis [135] (Table 2).

Table 2. Nanoformulations including mi-RNA to overcome resistance in colorectal and pancreatic cancers.

\begin{tabular}{|c|c|c|c|c|c|}
\hline CRC/PAC & Name & Status & Nanotransporter & Effect & Ref. \\
\hline & & DR & & & \\
\hline \multirow[t]{6}{*}{ CRC } & $\operatorname{miR}-375-3 p$ & & Lipid-coated calcium carbonate with 5-FU & $\begin{array}{l}\text { Inhibit TS and enhance chemosensitivity to } \\
\text { 5-FU }\end{array}$ & [136] \\
\hline & $\operatorname{miR}-200$ & & $\begin{array}{c}\text { Peptide-modified liposomes including solid lipid NPs } \\
\text { encapsulating IRI }\end{array}$ & $\begin{array}{l}\text { Increase cytotoxity of irinotecan and suppress } \\
\text { Wnt/ } \beta \text {-Catenin, MDR and EMT pathways }\end{array}$ & [137] \\
\hline & miR-204-5p & & $\begin{array}{c}\text { Mesoporous silica NPs assembled with OXA and } \\
\text { PEE/HA }\end{array}$ & $\begin{array}{l}\text { Generate a synergisti effect with OXA due to an } \\
\text { increased internalization via CD44 receptor }\end{array}$ & [138] \\
\hline & & & PEGylated polymer NPs & $\begin{array}{l}\text { Inhibit cell proliferation and promote cell } \\
\text { apoptosis }\end{array}$ & [139] \\
\hline & miR-145 & & PEGylated polymer NPs & $\begin{array}{l}\text { Produce arrest cell cycle in GO/G1 phase, } \\
\text { reduce tumour proliferation, migration and } \\
\text { increase apoptosis by supressing } c-M Y C\end{array}$ & [140] \\
\hline & miR-139 & & Lipid polymeric NPs including Afatinib & $\begin{array}{l}\text { Induce apoptosis, inhibit migration and } \\
\text { resistance of cells via suppression of pan-HER } \\
\text { tyrosine kinase }\end{array}$ & [141] \\
\hline
\end{tabular}


Table 2. Cont

\begin{tabular}{|c|c|c|c|c|c|}
\hline \multirow[t]{5}{*}{ CRC/PAC } & Name & Status & Nanotransporter & Effect & Ref. \\
\hline & & DR & & & \\
\hline & & UR & & & \\
\hline & $\operatorname{miR}-21$ & & Fluorescent nanodiamond & $\begin{array}{l}\text { Activates PDCD4 and TIMP3 genes resulting in } \\
\text { a decrease of cell invasion, migration an } \\
\text { induction of apoptosis }\end{array}$ & [142] \\
\hline & miR-155 & & $\begin{array}{c}\text { Mesoporous silica NPs with polymerized dopamine } \\
\text { and AS1411 aptamer }\end{array}$ & $\begin{array}{c}\text { Decrease tumour growth by targeting AS1411 } \\
\text { target (Nucleolin) }\end{array}$ & [143] \\
\hline \multirow[t]{11}{*}{ PAC } & $\operatorname{miR}-150$ & & $\begin{array}{c}\text { poly (D, L-lactide-co-glycolide)-based } \\
\text { nanoformulation }\end{array}$ & $\begin{array}{l}\text { Supress tumour growth, motility and invasion } \\
\text { by decreasing MUC4 and HER } 2 \text { expression } \\
\text { Inhibit cell proliferation, migration and }\end{array}$ & [144] \\
\hline & miR-145 & & Magnetic NP formulation & $\begin{array}{c}\text { invasion by reducing } M U C 13, H E R 2 \text { and } p A K T \\
\text { expression }\end{array}$ & [145] \\
\hline & miR-216b & & $\begin{array}{l}\text { Palmityl-oleyl-phosphatidylcholine liposomes } \\
\text { conjugated with cell penetrating peptide }\end{array}$ & $\begin{array}{l}\text { Engage } A G O 2 \text { to promote the silencing of } \\
\text { KRAS which decrease the cell proliferation and } \\
\text { the capacity of colony formation }\end{array}$ & [146] \\
\hline & miR-211 & & Chimeric peptide with Plectin- 1 target peptides & $\begin{array}{l}\text { Decrease USP99X expression and enhance DOX } \\
\text { induced apoptosis and autophagy } \\
\text { Improve the effect of DOX through }\end{array}$ & [147] \\
\hline & miR-9 & & Chimeric peptide with plectin-1 target peptides & $\begin{array}{c}\text { downregulating eIF2 expression which induce } \\
\text { apoptosis }\end{array}$ & [148] \\
\hline & $\operatorname{miR}-873$ & & Nanoliposomes & $\begin{array}{l}\text { Suppress cell proliferation, migration, invasion } \\
\text { and tumorigenesis by inhibiting the } \\
\text { KRAS/ERK/PI3K pathways }\end{array}$ & [149] \\
\hline & $\operatorname{miR}-634$ & & Lipid NPs & $\begin{array}{l}\text { Decrease the cellular proliferation by inducing } \\
\text { apoptosis through targeting XIAP, APIP, BIRC5 }\end{array}$ & [150] \\
\hline & & UP & & & \\
\hline & miR-210 & & Cholesterol NPs with CXCR4 antagonist & $\begin{array}{c}\text { Modulation of tumour microenvironment and } \\
\text { inhibition of metastasis }\end{array}$ & [151] \\
\hline & miR-21 & & $\begin{array}{c}\text { PEG-PE magnetic iron oxide NPs delivered with GEM } \\
\text { and coated of anti-CD } 44 \mathrm{v} 6\end{array}$ & $\begin{array}{l}\text { Inhibit proliferation and metastasis by } \\
\text { increasing PDCD4 and PTEN gene expression }\end{array}$ & [152] \\
\hline & miR-21-5P & & Tumour penetrating NPs & $\begin{array}{c}\text { Decrease the proliferation and induce apoptosis } \\
\text { by targeting KRAS gene }\end{array}$ & [153] \\
\hline
\end{tabular}

Downregulated (DR); upregulated (UR); reference (Ref); nanoparticles (NPs); 5-fluorouracil (5-FU); oxaliplatin (OXA); gemcitabine (GEM); MDR (multidrug resistance); EMT (epithelial-mesenchymal transition); polyethyleneimine/hyaluronic acid (PEE/HA); irinotecan (IRI); Programmed Cell Death 4 protein (PDCD4); Metallopeptidase Inhibitor 3 (TIMP3); nuclear factor kappa-lightchain-enhancer of activated B cells (NF- $\mathrm{kB}$ ); polyethylene glycol-polyethyleneimine (PEG-PEE); C-X-C Motif Chemokine Receptor 4 (CXCR4); thymidylate synthase enzyme (TS); mucin 4 (MUC4); human epidermal frowth factor receptor 2 (HER2); mucin 3 (MUC13); AKT Serine/Threonine Kinase 1 (pAKT1); argonaute-2 (AGO2); eukaryotic initiation factor 2 (EIF2); $x$-linked inhibitor of apoptosis (XIAP); APAF1 interacting protein (APIP); Baculoviral IAP repeat containing 5 (BIRC5); phosphatase and tensin homolog (PTEN); cellular transforming proto-oncogene (KRAS).

\section{1. miRNAs in Colorectal Cancer}

miR-375-3p targets the thymidylate synthase (TYMS) enzyme, which regulates drug resistance to 5-FU. The expression of TYMS was found to be increased in HCT116 cells and in the 5-FU-resistant cell line HCT-15/Fu. miR-375-3p was downregulated in the colon cancer cell lines SW480, HCT116, HT29 and Caco2 compared to the non-tumor colon cell line NCM460. Xu, et al. [136] demonstrated that miR-375-3p associated with 5-FU and loaded in calcium carbonate and lipid-coated NPs improved chemo-sensitivity to 5-FU and inhibited cell proliferation, both in vitro and in vivo. A similar effect was described using miR-200 associated with Irinotecan-loaded liposomes coated with PEG peptides, which reduced the growth of HCT116 colon cancer cells. This effect was also observed in tumor-bearing mice through the suppression of EMT, MDR, B-catenin and apoptosis signaling pathways [137].

Other miRNAs associated with a nanosystem were assayed in colon cancer treatment, including miR-204-5p, miR-145, miR-139, miR-21 and miR-155. The miR-204-5p, an important tumor suppressor factor, is downregulated in colon cancer. This miRNA was incorporated in pegylated polymer NPs, showing an antiproliferative effect in HCT-116 colon and HT-29 lung cancer cells in a tumor xenograft model [139]. miR-145, also downregulated in colon cancer cells, and PLGA/PEI/HA nanocomplexes were used to increase the expression of miRNA-145 in the tumor tissue of a xenograft model from HCT-166 colon cancer cells. This treatment induced cell cycle arrest in the G0/G1 phase, decreased tumor proliferation and migration, and increase apoptosis [140]. As mentioned above, EGFR is known to be overexpressed in colon cancer. miR-139 was combined with afatinib, an oral 
tyrosine kinase and EGFR inhibitor, into lipid polymeric NPs conjugated with a targeting ligand and a $\mathrm{pH}$-sensitive penetrating peptide (Afa/LPN-HR). The results showed that these NPs induced apoptosis, inhibited cell migration and decreased drug resistance to Afatinib in Caco-2 cells by modulating the EGFR, HER, Ras, Akt, Stat4, Mapk, EMT and Bcl pathways [141]. Finally, some systems have been developed to inhibit oncogenic miRNAs. A nanosystem consisting of fluorescent nanodiamond and antisense RNA was used to eliminate the oncogenic microRNA-21 in CT-26 colon cancer cells. The effect was the activation of the PDCD4 and Timp3 tumor suppressor genes, resulting in a decrease in cell invasion, migration and induction of apoptosis [142]. In addition, a nanoplatform consisting of anti-miR-155 loaded in mesoporous silica NPs (MSNs-anti-miR-155-PDA-Apt) was used to reduce the expression of miR-155 in SW480 cells and in in vivo experiments. This nanoplatform exhibited an antiproliferative effect due to the active targeting of the AS1411 aptamer and passive targeting of the EPR effect. In addition, they re-sensitized 5-FU-resistant tumors by reducing p-GP [143].

\section{2. miRNAs in Pancreatic Cancer}

Nanoformulations using miRNAs (e.g., miR-145, miR-21, miR-216b, miR-210, miR634, miR-211 or miR-210) to overcome drug resistance have also been tested in PAC. HPAF-II and AsPc-1 PAC cells showed downregulation of the miR-145 tumor suppressor miRNA. In addition, a magnetic NP formulation (miR-145-MNOF) was able to restore and increase miRNA expression, reducing the levels of MUC13, HER2 and $p A K T$, and inhibiting cell proliferation, migration and invasion [145]. Li, et al. [152] used miR-21 antisense oligonucleotides (ASO-miR-21) and GEM associated with PEG-polyethylenimine-magnetic iron oxide NPs and an anti-CD44v6 single-chain variable fragment against PANC-1 and MIA PaCa-2 PAC cells. This system decreased the expression of miR-21 and increased the expression of the PDCD4 and PTEN tumor-suppressor genes. In the same two cell lines, single-stranded (SS) miR-216b included into palmityl-oleyl phosphatidylcholine (POPC) liposomes conjugated with two palmityl chains and a cell penetrating peptide (TAT) was able to restore the expression of miR-216b, which was downregulated. Moreover, this system suppressed the oncogenic KRAS and inhibited colony formation in both PANC-1 and MIA PaCa-2 cell lines [146]. KRAS is a proto-oncogene frequently mutated in pancreatic ductal adenocarcinoma (PDAC). The possibility of blocking oncogenic pathways involving KRAS-induced ERK/AKT signaling is a promising therapeutic strategy. Mokhlis, et al. [149] overexpressed miR-873 in Capan-2, Mia Paca-2, PANC-1 and BxPc-3 pancreatic cell lines and in an orthotopic xenograft mouse model to induce apoptosis. In addition, dual targeting of miR-21 (anti-miR-21) and KRAS (siKRAS or mimic-217) packaged into the tumor-penetrating NPs decreased tumor growth in in vivo models generated from PANC1 and D8-175 PDAC cell lines [153]. The administration of si-KRAS and anti-miR-210 loaded in cholesterol NPs in an in vivo model modulated the TME, led to a delay of tumor growth and inhibition of metastasis, and prolonged survival [154]. microenvironment is especially relevant in PADC due to its lack of vascularization and the presence of a dense stroma. On the other hand, the enforced expression of some miRs such as miR-634 can induce apoptosis in cancer cells by modulating the expression of genes associated with anti-apoptotic signaling, mitochondrial homeostasis, cytoprotective processes and autophagy. In this context, LNPs harboring miR-634 showed therapeutic potential against a xenograft tumor from BxPC-3 PAC cells in mice [150].

Finally, peptides targeting plectin (PL-1), a novel biomarker for PAC, have shown high specificity for PDAC in in vivo experiments. A chimeric peptide (PL-1) associated with miR-211 in supramolecular NPs decreased the expression of USP99X and enhanced the effect of DOX (apoptosis and autophagy) on CFPAC-1, CAPAN-1, PAN-198 and PANC-1 PAC cells [147]. A similar system using miR-9 improved the anticancer effect of DOX by downregulating the expression of Eif5a2 in CFPAC-1, CAPAN-1, PAN-198 and PANC-1 cells and in a PAC patient-derived xenograft model [148] 


\section{Epigenetic Alterations}

Although many diagnosed tumors are caused by genetic factors, these do not explain all of the cases. Epigenetics studies have shown that the methylation of essential genes involved in an adequate regulation of cells (e.g., $p 53, A P C, R A S, P T E N$ or Wnt) gives rise to genetic instability, which ends up causing the development of CRC [155]. Similarly, epigenetic dysregulations related to the $p 16, P T E N$ and RAS genes, among others, can be found in certain cases of aggressive PAC [156,157]. In this context, epigenetic modifications and the existence of non-coding regulatory RNAs in our genome may influence drug resistance, becoming a potential target to improve cancer treatment.

There is a wide variety of epigenetic modifications that can occur in the DNA, histones and in nucleosome remodelling, but the most studied are methylation and acetylation. DNA methylation can inactivate genes which are necessary for the maintenance of the basal state of tissues, causing deregulation of tumor suppressor genes and leading to the development of CRC and PAC [158]. Cell lines resistant to 5-FU showed epigenomic changes in the expression of genes influencing the process of resistance [159]. Other epigenetic modulations that induce downregulation of the PCAF acetyltransferase increased resistance to 5-FU in colon cancer by reducing drug-induced apoptosis [160]. In addition, the overexpression of the arginine methyltransferase 3 (PRMT3) protein, which allows the expression of the $A B C G 2$ gene, increased chemoresistance in PAC cell lines [161].

Since DNA methylation is one of the modifications most frequently involved in cancer (including CRC and PAC), several treatment strategies focused on this epigenetic process have been designed. Accordingly, Gd-metallofullerenol nanomaterials were able to inhibit the interaction between histone deacetylase I (HDAC1) and metastasis-associated protein (MTA1), suppressing cell invasion and metastasis in PAC [162]. Valproic acid, an HDAC2 inhibitor, was encapsulated in polysaccharide NPs, allowing its hemocompatibility and avoiding toxicity [163]. In addition, other HDAC inhibitors, such as vorinostat and quisinostat, were associated with PLGA-lecithin-PEG NPs to increase the radiosensitization of these tumors [164]. More recently, Kularatne, et al. [165]) developed polycaprolactone polymer NPs associated with 4-phenylbutyric acid, an HDAC inhibitor, to enhance DOXbased therapy in CRC, while Busi, et al. [166] developed keratin NPs loaded with 9hydroxystearic acid, another HDAC1 inhibitor, which induced cell cycle arrest and cell death in CRC lines.

\section{Drug Resistance and Tumor Microenvironment}

The TME is a highly complex and heterogeneous set made up not only of cancer cells, but also of immune system and epithelial cells, in addition to the substances which these secrete. The feedback between tumor cells and their environment allows reciprocal adaptations in order to overcome stressful situations and increase tumor survival [167]. Most tumors contain hypoxic areas in which the hypoxia-inducible factor 1 alpha (HIF-1 $\alpha)$ is overexpressed. This factor is responsible for the transcription of numerous genes related to altered metabolism, angiogenesis, or metastatic progression $[168,169]$. HIF- $1 \alpha$ can lead to an accumulation of pyruvate and nicotinamide adenine dinucleotide (NADH) and induction of the expression of lactate dehydrogenase A (LDHA), increasing the levels of lactate in the extracellular medium (ECM), with its subsequent acidification [168]. Hypoxia can also induce angiogenesis in the surrounding endothelial cells by releasing the VEGF-A, or promote myofibroblast differentiation through the expression of transforming growth factor- $\beta$ (TGF- $\beta$ ) [169-171]. Thus, hypoxic areas favor the expression of drug resistance factors that lead to decreased effectiveness of treatments. Some strategies based on the use of NPs focus on hypoxic-related conditions, $\mathrm{pH}$ status or neovacularization to improve the action of drugs and avoid resistance (Figure 3). Javan, et al. [172] based their approach on the development of a hypoxia-sensitive system. The authors created a vector composed of shRNAs for $\beta$-catenin and $B c l-2$ driven by the promoter for carcinoembryonic antigen (CEA) and VEGF, loaded in PEI/Thiolated-chitosan NPs. In hypoxia conditions, this system inhibited the expression of Bcl-2 and $\beta$-catenin by $51 \%$ and $56 \%$, respectively, 
and increased the rates of apoptosis by $40 \%$ in HT29 CRC cells. In addition, hypoxiasensitive systems have been assayed in CRC to increase the oxygen levels, reducing hypoxia and, consequently, drug resistance. In fact, Meng, et al. [173] functionalized human serum albumin (HSA)-PTX-NPs with MnO2, increasing the concentration of O2 and destabilizing HIF- $1 \alpha$ (58.93\% reduction) in mice bearing CT26 tumors. Subsequent radiation of the tumor achieved a synergistic effect due to increased tumor oxygenation, inhibiting tumor growth by $96.57 \%$. Furthermore, gold nanocages functionalized with $\mathrm{MnO} 2$ and hyaluronic acid (HA) eliminated hypoxic areas and boosted $\mathrm{O} 2$ production after near-infrared (NIR) irradiation in CRC [174]. Aljabali, et al. [175] used piceatannol (resveratrol analog) associated with bovine serum albumin (BSA) to reduce the expression of HIF- $1 \alpha$ and $p 62$ in CRC (Caco-2 and HT29 cells).

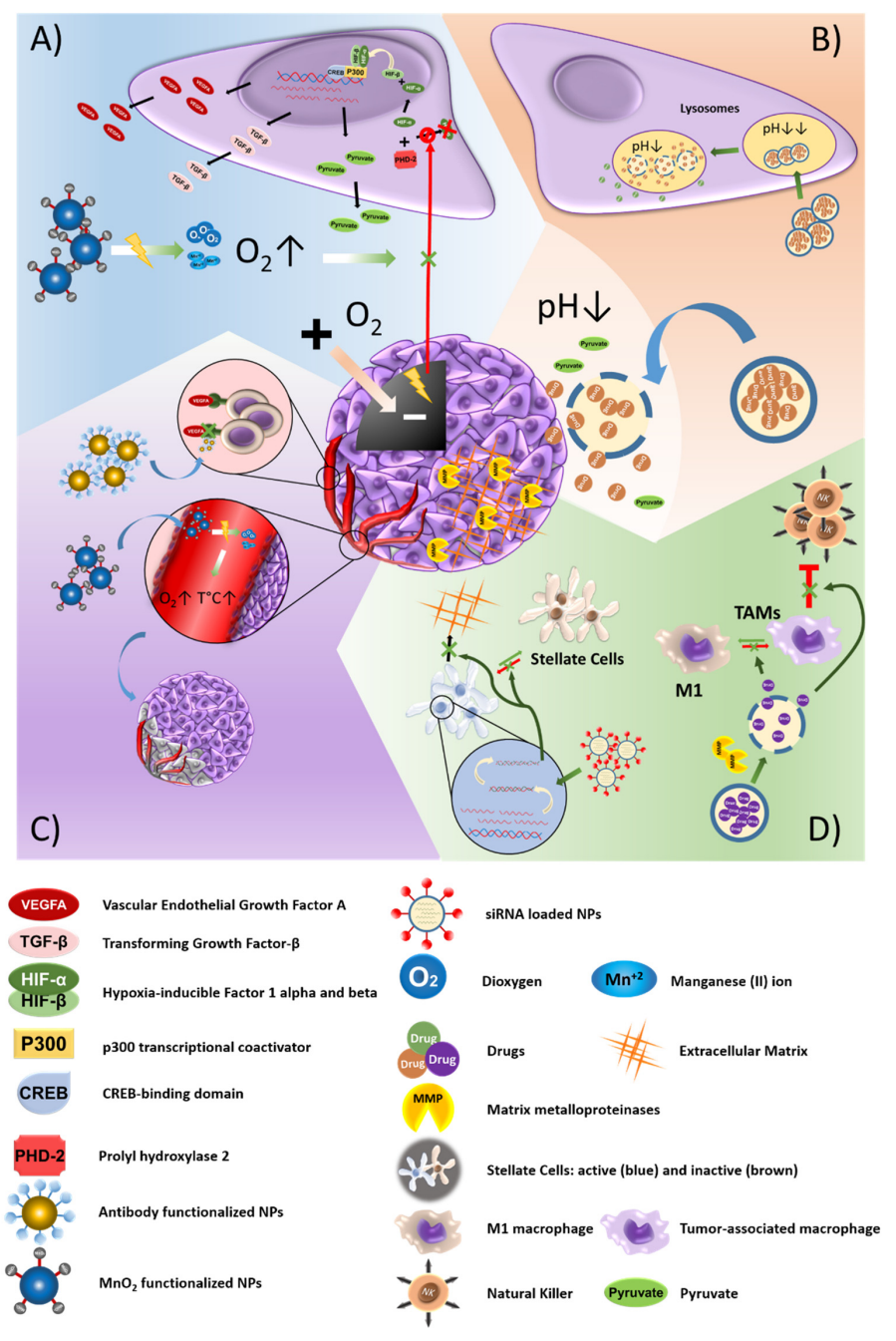

Figure 3. Nanoparticle-based strategies to exploit the characteristics of the tumor microenvironment (TME). (A) Systems that focus on the presence of hypoxic areas are based on the generation of oxygen, increasing its local levels and, therefore, eliminating the stress situation which results from hypoxia. Reversal of the hypoxic state blocks the expression of HIF-1 $\alpha$ and, consequently, reduces the acidification of the extracellular medium and the expression of pro-angiogenic factors. (B) Medium acidification can be exploited by using $\mathrm{pH}$-sensitive nanoplatforms with the aim of both achieving a controlled release of their load and buffering the medium to reestablish the $\mathrm{pH}$. (C) Some strategies also focus on the active targeting of the neo-vasculature through the use of NPs that specifically recognize it by means of antibodies and the application of radiation. (D) In addition, some cellular components of the TME can be reprogrammed by using certain drugs, or inactivated by vehiculation of siRNA. 
In PAC, iRGD-functionalized pegylated polymersomes associated with azobenzene improved the release of GEM in hypoxic conditions, both in vitro and in vivo [176]. In addition, Chen, et al. [177] aimed to overcome the limitations of hypoxia in PAC by using a fluorocarbon-functionalized hollow mesoporous organosilica NPs. These NPs acted as $\mathrm{O} 2$ scavengers and included the IR780 sonosensitizer to improve the effectiveness of ultrasound irradiation. Co-treatment with NPs and ultrasound irradiation produced a significant increase in the concentration of oxygen and reactive oxygen species (ROS). This led to increased and maintained partial pressure of oxygen in the tumor in PANC-1 tumor-bearing mice, reversing the hypoxic state of the TME, increasing the survival rate and inhibiting tumor growth.

Finally, some cell types present in the TME, such as macrophages, fibroblasts, and stellate cells, can promote drug resistance in the tumor due to the excessive release of cytokines and components of the ECM, such as collagen or fibronectin. Accordingly, these components have also been the target of NP-based therapeutic strategies aimed at reducing drug resistance. Tumor-associated macrophages (TAMs), which exhibit a phenotype similar to M2 polarized macrophages, limit the performance of lymphocytes and natural killers. Taking advantage of the overexpression of matrix metalloproteinases (MMPs) and esterases in the TME, Liu, et al. [178] synthesized ruthenium-based nanoplatforms functionalized with triglyceride monostearates (TGMs) for a controlled release of iBLZ-945, an inhibitor of the CSF-1/CSF-1R pathway. These nanocomplexes reversed the TAM M2 phenotype to a pro-inflammatory M1 phenotype. In fact, in CRC (CT26 cells)-bearing mice, co-treatment with these nanoplatforms and photodynamic irradiation achieved a 1.4-fold increase in CD8+ T lymphocyte infiltration. These results were explained by the reversal of the TAM phenotype to M1 resulting from the elevation of ROS levels after PDT [178]. TAMs were also used by Cao, et al. [179] to design a system based on PEG-PLGA NPs functionalized with the YI peptide to improve PTX administration. The YI peptide specifically recognizes legumarin, a surface marker of TAMs, and the ANXA1 protein present in the vasculature of the tumor. The administration of these nanoplatforms in HT-29 tumor-bearing mice resulted in high accumulation within the tumor ( 3-fold) and in increased concentration of PTX ( 5-fold).

The accessibility of treatments to the tumor is hindered in PAC due to the presence of a particularly dense tumor stroma (desmoplasia), which promotes resistance. This abnormal stroma results from an excessive production of cytokines and ECM proteins, caused by the altered activity of pancreatic stellate cells (PSCs) and cancer-associated fibroblasts (CAFs). Accordingly, PSCs are another target in PAC treatment. Xie, et al. [151] synthetized multifunctional nanoplatforms, including PCX (CXCR4 antagonist), anti-miR-210 (which inactivates PSCs) and siKRASG12D (KRAS inhibitor) (PCX/(anti-miR-210+siKRASG12D). The intraperitoneal administration of these nanoplatforms in KPC8060 (mutant KRASG12D and $p 53$ ) orthotopic tumor-bearing mice effectively decreased the expression of miR-210 $(76 \%)$, Ki77+ cells $(74 \%)$ and KRASG12D $(74 \%)$, and reduced the expression of collagen and $\alpha$ SMA in PSCs. In addition, this treatment led to a greater infiltration of CD8+ T cells and a decrease in TAMs at the tumor site. By contrast, Han, et al. [180] tried to "re-educate" PSCs by using PEG-PEI-AuNPs to administer all-trans retinoic acid (ATRA) and siHSP47 (heat shock protein 47) (Au@PP/RA/siHSP47). The authors reported a 55\% reduction in the expression of HSP47 in PANC-1/PSC tumor xenografts, and a lower expression of fibronectin and collagen in the ECM. In addition, co-treatment with GEM allowed to reduce the tumor weight ( $60 \%)$ compared to GEM alone.

\section{Cancer Stem Cells and Drug Resistance}

CSCs, a small subset of tumor cells with self-renewal capacity and tumorigenicity, are currently considered one of the primary causes of chemo- and radioresistance $[167,181]$. The main strategies developed to specifically target CSCs and eliminate resistance to treatment take advantage of the overexpression of pluripotency markers or molecules related to cell cycle alterations and cell survival. 
In CRC, most of the alternatives studied involve the use of HA due to its specific binding to CD44, a marker overexpressed in this tumor. Recently, 6-mercaptopurine and thiolated HA hydrophobic based polymeric micelles selectively enhanced the effect of DOX in HCT116 colon cancer cells, showing no toxicity in normal L929 fibroblast cells [182]. Li, et al. [183] developed a multifunctional nanoplatform using RRPH (HAPEG polymer) conjugated with the R8-RGD tandem peptide to efficiently and selectively transfect CSCs with the tumor necrosis factor (TNF)-related apoptosis-inducing ligand (TRAIL) gene associated with PF33 (fluorinated polymer). In vivo assays showed that nanoplatforms carrying the TRAIL gene were able to escape endosomes and accumulate in the nucleus of HCT116 CRC cells, significantly reducing their volume without altering other organs or modifying the blood chemistry profile. The CSC marker CD133 was the main target of the nanoplatform designed by Zahiri, et al. [184] to deliver DOX encapsulated in dendritic mesoporous silica NPs functionalized with an RNA aptamer against CD133. This nanosystem increased the toxicity of DOX in HT29 colon cancer cells as a result of greater cellular internalization. Moreover, a nanoplatform based on the ability to self-assemble of the diphtheria toxin together with the CXCR4 ligand T22 associated with 5-FU or OXA, eliminated the proliferative potential of CSC from mice tumors derived from CRC patient cells [185]. Finally, the polymeric micelles designed by Montero, et al. [186] loaded with anti-structural maintenance of chromosomes protein 2 (SMC2) antibodies and 5-FU were capable of overcoming resistance to 5-FU in HCT116 cells.

In PAC, the most recent studies used metal-based nanoplatforms such as titanium, iron, gold and copper to target pancreatic CSCs. Wang, et al. [187] designed a nano-platform for PTT based on black TiO2 loaded with Gd-DOTA and targeted with anti-CD133mAb, achieving a higher and selective death of CSCs. Additionally, AuNPs [188] or curcuminloaded superparamagnetic iron oxide NPs (SPIONs-CUR) [189] reduced resistance to GEM. AuNPs not only decreased the ability to form colonies (2D or 3D) in PAC cells, but also led to exponential decrease in the IC50 of GEM. Moreover, these NPs downregulated the expression of pancreatic CSC markers (CD24, CD44, Epcam, CXCR4, DCLK1, nestin, CD133, c-Met, ALDH and Tspan8), N-cadherin and vimentin, and upregulated E-cadherin [188]. On the other hand, SP-CUR combined with GEM, at doses at which this drug alone is not effective, selectively reduced the viability of pancreatic CSCs by $50 \%$ due to the inhibition of factors such as Nanog, Sox-2, CD133 and Oct-4 [189]. Also, copper-based nanoplatforms have been shown to selectively cause toxicity in CSCs by generating high levels of oxidative stress (ROS). In fact, Marengo, et al. [190] developed HA-functionalized PEG-liposomes loaded with copper complexes (Cu(DDC)2) and formed by the diethyldithiocarbamate (DDC) present in disulfiram (DSF), which reduced the DSF IC50 (2-fold) in PANC-1 CSCs. This same author used LipoCu(DDC)2-2\%PEG3\%HA17000 NPs to achieve a 17.5-fold reduction in the IC50 of DDC, in addition to inhibiting the ability of CSCs to form tumorspheres. Recently, Azmi, et al. [191] co-administered Selinexor and nab-PTX+GEM, improving the cytotoxic effect of the drugs and inhibiting the ability of CSCs to form tumors. In fact, a phase $\mathrm{Ib}$ trial using this combined therapy achieved $40 \%$ partial response and $40 \%$ disease stability rates in patients with PAC (Figure 4). 


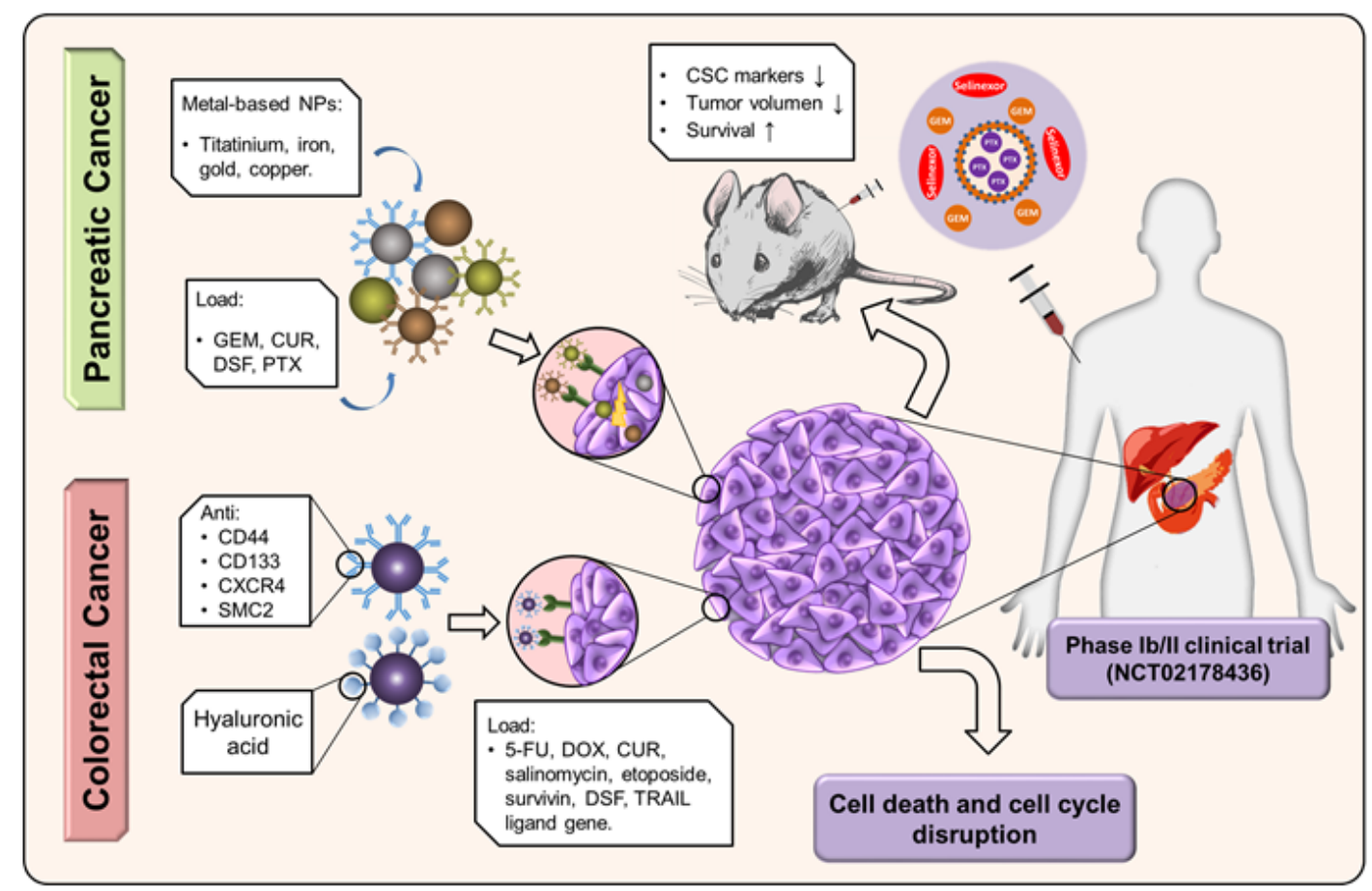

Figure 4. Main nanoplatforms used to overcome drug resistance in colon and pancreatic CSCs. While the CRC tends to use approaches with active targeting NPs to improve the entry of drugs, the PC opts for the use of metal-based NPs that are actively targeted or not.

\section{Conclusions}

Gastrointestinal cancers, including CRC and PAC, frequently develop drug resistance mechanisms, preventing adequate treatment and leading to poor prognosis. Most patients with CRC, especially in metastatic stages, develop acquired drug resistance. Despite the identification of several resistance mechanisms, this phenomenon is extremely complex because it continues to develop during tumorigenesis, is dependent on the administered therapy and can be induced by several mechanisms simultaneously. Although preclinical studies combining conventional treatments with drugs such as $A B C$ transporter inhibitors, EGFR inhibitors or autophagy inducers, have reduced drug resistance, clinical trials have not been successful. On the other hand, PAC, a refractory disease with high mortality, is also known to develop resistance, preventing drugs from exerting their antitumor effects. In this case, multiple molecular mechanisms related to resistance have been described, such as inhibition of DNA repair pathways or down-regulation of miRNA, but the development of a dense hypovascularized stroma is the essential factor underlying this phenomenon. Despite the most recent advances, clinical trials using strategies to avoid resistance have failed, although there are currently some studies in preliminary phases that try to avoid this phenomenon (Table 3). In this context, the use of novel nanoformulations seeks to provide systems that not only increase drug circulation time and accumulation in tumor tissue, but also the ability to transport therapeutic combinations with potential to overcome MDR. Of note, the development of these nanodrugs is based upon knowledge of resistance mechanisms. Accordingly, in addition to transporting drugs commonly used for colon or pancreatic cancer treatment, they allow to inhibit efflux proteins, modulate the expression of miRNA or increase the selectivity for hypoxic environments. In summary, drug resistance continues to be an obstacle for the effective application of chemotherapy. The development of new nanodrugs will undoubtedly represent an excellent therapeutic strategy to eliminate or minimize resistance in CRC and PAC. 
Table 3. Clinical trials using NPs designed against CRC and PAC to overcome multidrug resistance.

\begin{tabular}{cccc}
\hline Identifier & Drug/Cargo & Clinical Phase & PAC/CRC \\
\hline NCT02178436 & Selinor + GEM + nab-paclitaxel & Phase Ib & PAC \\
NCT02010567 & CRLX101-capecitabine + & Phase I/II & CRC \\
NCT00081549 & Aroplatin (liposomal NDDP) + GEM & Phase I/II & PAC \\
NCT00043199 & Aroplatin (liposomal NDDP) & Phase II & CRC \\
NCT00081536 & Aroplatin + capecitabine & Phase I/II & CRC \\
NCT03883919 & IRI+5-FU/LV + paricalcitol & Pilot Study & PAC \\
NCT03337087 & Liposomes transporting IRI, 5-FU, & Phase I/II & PAC and CRC \\
\multicolumn{2}{l}{ Gemcitabine (GEM); bis-neodecanoate diaminocyclohexane platinum (NDDP); irinotecan (IRI); 5-fluorouracil } \\
(5-FU); leucovorin (LV).
\end{tabular}

Author Contributions: Conceptualization, R.O., C.M. (Consolación Melguizo) and J.P.; methodology, F.Q., B.G.-P. and M.F.; software, C.M. (Cristina Mesas), and L.C.; validation, C.M. (Cristina Mesas) and L.C.; writing—original draft preparation, R.O., F.Q. and B.G.-P.; writing-review and editing, R.O. and C.M. (Consolación Melguizo); supervision, R.O. and J.P.; funding acquisition, R.O. and J.P. All authors have read and agreed to the published version of the manuscript.

Funding: This work was funded by the Consejería de Salud de la Junta de Andalucía (projects PI-0102-2017 and P18-HO-3882) and by the CTS-107 Group. This research was partially supported by a grant from the Instituto de Salud Carlos III (ISCIII) (Project PI19/01478) (FEDER).

Acknowledgments: The authors would like to thank technical assistance from the Centro de Instrumentación Científica (CIC) and Biomedical Library (University of Granada).

Conflicts of Interest: The authors declare no conflict of interest.

\section{References}

1. Bray, F.; Ferlay, J.; Soerjomataram, I.; Siegel, R.L.; Torre, L.A.; Jemal, A. Global cancer statistics 2018: GLOBOCAN estimates of incidence and mortality worldwide for 36 cancers in 185 countries. Ca A Cancer J. Clin. 2018, 68, 394-424. [CrossRef]

2. Ferlay, J.; Colombet, M.; Soerjomataram, I.; Mathers, C.; Parkin, D.M.; Pineros, M.; Znaor, A.; Bray, F. Estimating the global cancer incidence and mortality in 2018: GLOBOCAN sources and methods. Int. J. Cancer 2019, 144, 1941-1953. [CrossRef]

3. Rawla, P.; Sunkara, T.; Barsouk, A. Epidemiology of colorectal cancer: Incidence, mortality, survival, and risk factors. Prz. Gastroenterol. 2019, 14, 89-103. [CrossRef]

4. Housman, G.; Byler, S.; Heerboth, S.; Lapinska, K.; Longacre, M.; Snyder, N.; Sarkar, S. Drug resistance in cancer: An overview. Cancers 2014, 6, 1769-1792. [CrossRef]

5. Wang, X.; Zhang, H.; Chen, X. Drug resistance and combating drug resistance in cancer. Cancer Drug Resist. 2019, 2, 141-160. [CrossRef]

6. Hientz, K.; Mohr, A.; Bhakta-Guha, D.; Efferth, T. The role of p53 in cancer drug resistance and targeted chemotherapy. Oncotarget 2017, 8, 8921-8946. [CrossRef] [PubMed]

7. Cercek, A.; Fernandes, G.D.S.; Roxburgh, C.S.; Ganesh, K.; Ng, S.; Sanchez-Vega, F.; Yaeger, R.; Segal, N.H.; Reidy-Lagunes, D.L.; Varghese, A.M.; et al. Mismatch Repair-Deficient Rectal Cancer and Resistance to Neoadjuvant Chemotherapy. Clin. Cancer Res. J. Am. Assoc. Cancer Res. 2020, 26, 3271-3279. [CrossRef]

8. Liang, M.; Zhao, T.; Ma, L.; Guo, Y. CHK1 inhibition sensitizes pancreatic cancer cells to gemcitabine via promoting CDKdependent DNA damage and ribonucleotide reductase downregulation. Oncol. Rep. 2018, 39, 1322-1330. [CrossRef] [PubMed]

9. Ceballos, M.P.; Rigalli, J.P.; Cere, L.I.; Semeniuk, M.; Catania, V.A.; Ruiz, M.L. ABC Transporters: Regulation and Association with Multidrug Resistance in Hepatocellular Carcinoma and Colorectal Carcinoma. Curr. Med. Chem. 2019, 26, 1224-1250. [CrossRef] [PubMed]

10. Noordermeer, S.M.; van Attikum, H. PARP Inhibitor Resistance: A Tug-of-War in BRCA-Mutated Cells. Trends Cell Biol. 2019, 29, 820-834. [CrossRef] [PubMed]

11. Yap, T.A.; Plummer, R.; Azad, N.S.; Helleday, T. The DNA Damaging Revolution: PARP Inhibitors and Beyond. Am. Soc. Clin. Oncol. Educ. Book. Am. Soc. Clin. Oncol. Annu. Meet. 2019, 39, 185-195. [CrossRef]

12. Najafi, M.; Farhood, B.; Mortezaee, K. Cancer stem cells (CSCs) in cancer progression and therapy. J. Cell. Physiol. 2019, 234, 8381-8395. [CrossRef]

13. Arena, S.; Bellosillo, B.; Siravegna, G.; Martinez, A.; Canadas, I.; Lazzari, L.; Ferruz, N.; Russo, M.; Misale, S.; Gonzalez, I.; et al. Emergence of Multiple EGFR Extracellular Mutations during Cetuximab Treatment in Colorectal Cancer. Clin. Cancer Res. J. Am. Assoc. Cancer Res. 2015, 21, 2157-2166. [CrossRef] 
14. Bertotti, A.; Papp, E.; Jones, S.; Adleff, V.; Anagnostou, V.; Lupo, B.; Sausen, M.; Phallen, J.; Hruban, C.A.; Tokheim, C.; et al. The genomic landscape of response to EGFR blockade in colorectal cancer. Nature 2015, 526, 263-267. [CrossRef] [PubMed]

15. Henke, E.; Nandigama, R.; Ergun, S. Extracellular Matrix in the Tumor Microenvironment and Its Impact on Cancer Therapy. Front. Mol. Biosci. 2019, 6, 160. [CrossRef] [PubMed]

16. Lepeltier, E.; Rijo, P.; Rizzolio, F.; Popovtzer, R.; Petrikaite, V.; Assaraf, Y.G.; Passirani, C. Nanomedicine to target multidrug resistant tumors. Drug Resist Updat 2020, 52, 100704. [CrossRef] [PubMed]

17. Sanchez, L.; Yi, Y.; Yu, Y. Effect of partial PEGylation on particle uptake by macrophages. Nanoscale 2017, 9, 288-297. [CrossRef] [PubMed]

18. Longley, D.B.; Johnston, P.G. Molecular mechanisms of drug resistance. J. Pathol. 2005, 205, 275-292. [CrossRef] [PubMed]

19. Yao, L.; Gu, J.; Mao, Y.; Zhang, X.; Wang, X.; Jin, C.; Fu, D.; Li, J. Dynamic quantitative detection of ABC transporter family promoter methylation by MS-HRM for predicting MDR in pancreatic cancer. Oncol. Lett. 2018, 15, 5602-5610. [CrossRef]

20. Mollazadeh, S.; Sahebkar, A.; Hadizadeh, F.; Behravan, J.; Arabzadeh, S. Structural and functional aspects of P-glycoprotein and its inhibitors. Life Sci. 2018, 214, 118-123. [CrossRef]

21. Waghray, D.; Zhang, Q. Inhibit or Evade Multidrug Resistance P-Glycoprotein in Cancer Treatment. J. Med. Chem. 2018, 61, 5108-5121. [CrossRef]

22. Adamska, A.; Falasca, M. ATP-binding cassette transporters in progression and clinical outcome of pancreatic cancer: What is the way forward? World J. Gastroenterol. 2018, 24, 3222-3238. [CrossRef] [PubMed]

23. Chan, L.M.; Lowes, S.; Hirst, B.H. The ABCs of drug transport in intestine and liver: Efflux proteins limiting drug absorption and bioavailability. Eur. J. Pharm. Sci. 2004, 21, 25-51. [CrossRef] [PubMed]

24. Ferreira, R.J.; dos Santos, D.J.; Ferreira, M.J. P-glycoprotein and membrane roles in multidrug resistance. Future. Med. Chem. 2015, 7, 929-946. [CrossRef] [PubMed]

25. Kathawala, R.J.; Gupta, P.; Ashby, C.R., Jr.; Chen, Z.S. The modulation of ABC transporter-mediated multidrug resistance in cancer: A review of the past decade. Drug Resist. Updat 2015, 18, 1-17. [CrossRef] [PubMed]

26. Mottino, A.D.; Catania, V.A. Hepatic drug transporters and nuclear receptors: Regulation by therapeutic agents. World J. Gastroenterol. 2008, 14, 7068-7074. [CrossRef]

27. Silva, R.; Vilas-Boas, V.; Carmo, H.; Dinis-Oliveira, R.J.; Carvalho, F.; de Lourdes Bastos, M.; Remiao, F. Modulation of Pglycoprotein efflux pump: Induction and activation as a therapeutic strategy. Pharm. Ther. 2015, 149, 1-123. [CrossRef]

28. Jiang, Y.; Guo, Z.; Fang, J.; Wang, B.; Lin, Z.; Chen, Z.S.; Chen, Y.; Zhang, N.; Yang, X.; Gao, W. A multi-functionalized nanocomposite constructed by gold nanorod core with triple-layer coating to combat multidrug resistant colorectal cancer. Mater. Sci. Eng. C Mater. Biol. Appl. 2020, 107, 110224. [CrossRef] [PubMed]

29. Xu, L.; Zhang, Z.; Ding, Y.; Wang, L.; Cheng, Y.; Meng, L.; Wu, J.; Yuan, A.; Hu, Y.; Zhu, Y. Bifunctional liposomes reduce the chemotherapy resistance of doxorubicin induced by reactive oxygen species. Biomater. Sci. 2019, 7, 4782-4789. [CrossRef]

30. Wang, B.; Wu, S.; Lin, Z.; Jiang, Y.; Chen, Y.; Chen, Z.S.; Yang, X.; Gao, W. A personalized and long-acting local therapeutic platform combining photothermal therapy and chemotherapy for the treatment of multidrug-resistant colon tumor. Int. J. Nanomed. 2018, 13, 8411-8427. [CrossRef] [PubMed]

31. Yuan, Z.; Yuan, Y.; Han, L.; Qiu, Y.; Huang, X.; Gao, F.; Fan, G.; Zhang, Y.; Tang, X.; He, X.; et al. Bufalin-loaded vitamin E succinate-grafted-chitosan oligosaccharide/RGD conjugated TPGS mixed micelles demonstrated improved antitumor activity against drug-resistant colon cancer. Int. J. Nanomed. 2018, 13, 7533-7548. [CrossRef]

32. Siddiqui, L.; Mishra, H.; Mishra, P.K.; Iqbal, Z.; Talegaonkar, S. Novel 4-in-1 strategy to combat colon cancer, drug resistance and cancer relapse utilizing functionalized bioinspiring lignin nanoparticle. Med. Hypotheses. 2018, 121, 10-14. [CrossRef]

33. Yan, W.; Tao, M.; Jiang, B.; Yao, M.; Jun, Y.; Dai, W.; Tang, Z.; Gao, Y.; Zhang, L.; Chen, X.; et al. Overcoming Drug Resistance in Colon Cancer by Aptamer-Mediated Targeted Co-Delivery of Drug and siRNA Using Grapefruit-Derived Nanovectors. Cell Physiol. Biochem. 2018, 50, 79-91. [CrossRef] [PubMed]

34. Chen, C.; Zhu, D.; Zhang, H.; Han, C.; Xue, G.; Zhu, T.; Luo, J.; Kong, L. YAP-dependent ubiquitination and degradation of $\beta$-catenin mediates inhibition of Wnt signalling induced by Physalin F in colorectal cancer. Cell Death Dis. 2018, 9, 591. [CrossRef]

35. Nagheh, Z.; Irani, S.; Mirfakhraie, R.; Dinarvand, R. SN38-PEG-PLGA-verapamil nanoparticles inhibit proliferation and downregulate drug transporter ABCG2 gene expression in colorectal cancer cells. Prog. Biomater. 2017, 6, 137-145. [CrossRef] [PubMed]

36. Dash, T.K.; Konkimalla, V.S.B. Selection and optimization of nano-formulation of P-glycoprotein inhibitor for reversal of doxorubicin resistance in COLO205 cells. J. Pharm. Pharm. 2017, 69, 834-843. [CrossRef] [PubMed]

37. Roh, Y.J.; Kim, J.H.; Kim, I.W.; Na, K.; Park, J.M.; Choi, M.G. Photodynamic Therapy Using Photosensitizer-Encapsulated Polymeric Nanoparticle to Overcome ATP-Binding Cassette Transporter Subfamily G2 Function in Pancreatic Cancer. Mol. Cancer Ther. 2017, 16, 1487-1496. [CrossRef] [PubMed]

38. Ellah, N.H.A.; Taylor, L.; Ayres, N.; Elmahdy, M.M.; Fetih, G.N.; Jones, H.N.; Ibrahim, E.A.; Pauletti, G.M. NF-kappaB decoy polyplexes decrease P-glycoprotein-mediated multidrug resistance in colorectal cancer cells. Cancer. Gene Ther. 2016, 23, 149-155. [CrossRef] [PubMed]

39. Pan, Z.Z.; Wang, H.Y.; Zhang, M.; Lin, T.T.; Zhang, W.Y.; Zhao, P.F.; Tang, Y.S.; Xiong, Y.; Zeng, Y.E.; Huang, Y.Z. Nuclear-targeting TAT-PEG-Asp8-doxorubicin polymeric nanoassembly to overcome drug-resistant colon cancer. Acta Pharm. Sin. 2016, 37, 1110-1120. [CrossRef] 
40. Parayath, N.N.; Nehoff, H.; Norton, S.E.; Highton, A.J.; Taurin, S.; Kemp, R.A.; Greish, K. Styrene maleic acid-encapsulated paclitaxel micelles: Antitumor activity and toxicity studies following oral administration in a murine orthotopic colon cancer model. Int. J. Nanomed. 2016, 11, 3979-3991. [CrossRef]

41. Huang, H.-C.; Mallidi, S.; Liu, J.; Chiang, C.-T.; Mai, Z.; Goldschmidt, R.; Ebrahim-Zadeh, N.; Rizvi, I.; Hasan, T. Photodynamic Therapy Synergizes with Irinotecan to Overcome Compensatory Mechanisms and Improve Treatment Outcomes in Pancreatic Cancer. Cancer Res. 2016, 76, 1066-1077. [CrossRef]

42. Xiao, B.; Zhang, M.; Viennois, E.; Zhang, Y.; Wei, N.; Baker, M.T.; Jung, Y.; Merlin, D. Inhibition of MDR1 gene expression and enhancing cellular uptake for effective colon cancer treatment using dual-surface-functionalized nanoparticles. Biomaterials 2015, 48, 147-160. [CrossRef] [PubMed]

43. Negi, L.M.; Jaggi, M.; Joshi, V.; Ronodip, K.; Talegaonkar, S. Hyaluronan coated liposomes as the intravenous platform for delivery of imatinib mesylate in MDR colon cancer. Int. J. Biol. Macromol. 2015, 73, 222-235. [CrossRef]

44. Lo, Y.L.; Liu, Y. Reversing multidrug resistance in Caco-2 by silencing MDR1, MRP1, MRP2, and BCL-2/BCL-xL using liposomal antisense oligonucleotides. PLoS ONE 2014, 9, e90180. [CrossRef]

45. Negi, L.M.; Talegaonkar, S.; Jaggi, M.; Verma, A.K.; Verma, R.; Dobhal, S.; Kumar, V. Surface engineered nanostructured lipid carriers for targeting MDR tumor: Part I. Synthesis, characterization and in vitro investigation. Colloids Surf. B Biointerfaces 2014, 123, 600-609. [CrossRef]

46. Meker, S.; Margulis-Goshen, K.; Weiss, E.; Braitbard, O.; Hochman, J.; Magdassi, S.; Tshuva, E.Y. Anti-proliferative activity of nano-formulated phenolato titanium(IV) complexes against cancer cells. Chemmedchem 2014, 9, 1294-1298. [CrossRef]

47. Bedi, D.; Gillespie, J.W.; Petrenko, V.A. Selection of pancreatic cancer cell-binding landscape phages and their use in development of anticancer nanomedicines. Protein. Eng. Des. Sel. 2014, 27, 235-243. [CrossRef]

48. Pedrini, I.; Gazzano, E.; Chegaev, K.; Rolando, B.; Marengo, A.; Kopecka, J.; Fruttero, R.; Ghigo, D.; Arpicco, S.; Riganti, C. Liposomal nitrooxy-doxorubicin: One step over caelyx in drug-resistant human cancer cells. Mol. Pharm. 2014, 11, 3068-3079. [CrossRef] [PubMed]

49. Yoshizawa, Y.; Ogawara, K.; Kimura, T.; Higaki, K. A novel approach to overcome multidrug resistance: Utilization of P-gp mediated efflux of paclitaxel to attack neighboring vascular endothelial cells in tumors. Eur. J. Pharm. Sci. 2014, 62, 274-280. [CrossRef]

50. Bai, F.; Wang, C.; Lu, Q.; Zhao, M.; Ban, F.Q.; Yu, D.H.; Guan, Y.Y.; Luan, X.; Liu, Y.R.; Chen, H.Z.; et al. Nanoparticle-mediated drug delivery to tumor neovasculature to combat P-gp expressing multidrug resistant cancer. Biomaterials 2013, 34, 6163-6174. [CrossRef] [PubMed]

51. Lo, Y.L.; Liu, Y.; Tsai, J.C. Overcoming multidrug resistance using liposomal epirubicin and antisense oligonucleotides targeting pump and nonpump resistances in vitro and in vivo. Biomed. Pharm. 2013, 67, 261-267. [CrossRef]

52. Papa, A.L.; Basu, S.; Sengupta, P.; Banerjee, D.; Sengupta, S.; Harfouche, R. Mechanistic studies of Gemcitabine-loaded nanoplatforms in resistant pancreatic cancer cells. BMC Cancer 2012, 12, 419. [CrossRef]

53. Riganti, C.; Voena, C.; Kopecka, J.; Corsetto, P.A.; Montorfano, G.; Enrico, E.; Costamagna, C.; Rizzo, A.M.; Ghigo, D.; Bosia, A. Liposome-encapsulated doxorubicin reverses drug resistance by inhibiting P-glycoprotein in human cancer cells. Mol. Pharm. 2011, 8, 683-700. [CrossRef]

54. Yim, H.; Na, K. Polycationic nanodrug covered with hyaluronic acid for treatment of P-glycoprotein overexpressing cancer cells. Biomacromolecules 2010, 11, 2387-2393. [CrossRef] [PubMed]

55. Joshi, P.; Vishwakarma, R.A.; Bharate, S.B. Natural alkaloids as P-gp inhibitors for multidrug resistance reversal in cancer. Eur. J. Med. Chem. 2017, 138, 273-292. [CrossRef]

56. Lee, G.; Joung, J.Y.; Cho, J.H.; Son, C.G.; Lee, N. Overcoming P-Glycoprotein-Mediated Multidrug Resistance in Colorectal Cancer: Potential Reversal Agents among Herbal Medicines. Evid. Based. Complement Altern. Med. 2018, 2018, 3412074. [CrossRef] [PubMed]

57. Moerman, L.; Dumolyn, C.; Boon, P.; De Vos, F. The influence of mass of [11C]-laniquidar and [11C]-N-desmethyl-loperamide on P-glycoprotein blockage at the blood-brain barrier. Nucl. Med. Biol. 2012, 39, 121-125. [CrossRef] [PubMed]

58. Stage, T.B.; Mortensen, C.; Khalaf, S.; Steffensen, V.; Hammer, H.S.; Xiong, C.; Nielsen, F.; Poetz, O.; Svenningsen, A.F.; RodriguezAntona, C.; et al. P-Glycoprotein Inhibition Exacerbates Paclitaxel Neurotoxicity in Neurons and Patients With Cancer. Clin. Pharm. Ther. 2020, 108, 671-680. [CrossRef] [PubMed]

59. Zhang, W.; Liu, M.; Yang, L.; Huang, F.; Lan, Y.; Li, H.; Wu, H.; Zhang, B.; Shi, H.; Wu, X. P-glycoprotein Inhibitor Tariquidar Potentiates Efficacy of Astragaloside IV in Experimental Autoimmune Encephalomyelitis Mice. Molecules 2019, 24, 561. [CrossRef]

60. Hollt, V.; Kouba, M.; Dietel, M.; Vogt, G. Stereoisomers of calcium antagonists which differ markedly in their potencies as calcium blockers are equally effective in modulating drug transport by P-glycoprotein. Biochem. Pharm. 1992, 43, 2601-2608. [CrossRef]

61. Choi, Y.H.; Yu, A.M. ABC transporters in multidrug resistance and pharmacokinetics, and strategies for drug development. Curr. Pharm. Des. 2014, 20, 793-807. [CrossRef]

62. Yuan, Z.; Shi, X.; Yuan, Y.; Qiu, Y.; Zou, Y.; Liu, C.; Yu, H.; He, X.; Xu, K.; Yin, P. Bufalin reverses ABCB1-mediated drug resistance in colorectal cancer. Oncotarget 2017, 8, 48012-48026. [CrossRef]

63. Bernier, M.; Catazaro, J.; Singh, N.S.; Wnorowski, A.; Boguszewska-Czubara, A.; Jozwiak, K.; Powers, R.; Wainer, I.W. GPR55 receptor antagonist decreases glycolytic activity in PANC-1 pancreatic cancer cell line and tumor xenografts. Int. J. Cancer 2017, 141, 2131-2142. [CrossRef] 
64. Singh, N.S.; Bernier, M.; Wainer, I.W. Selective GPR55 antagonism reduces chemoresistance in cancer cells. Pharm. Res. 2016, 111, 757-766. [CrossRef] [PubMed]

65. Pan, M.R.; Hsu, M.C.; Luo, C.W.; Chen, L.T.; Shan, Y.S.; Hung, W.C. The histone methyltransferase G9a as a therapeutic target to override gemcitabine resistance in pancreatic cancer. Oncotarget 2016, 7, 61136-61151. [CrossRef]

66. Joshi, N.; Shanmugam, T.; Deshmukh, A.; Banerjee, R. Apoptotic cascade inspired lipid nanovesicles show synergism with encapsulated paclitaxel in chemoresistant colon carcinoma. Nanomedicine 2014, 9, 1789-1805. [CrossRef] [PubMed]

67. Kartal-Yandim, M.; Adan-Gokbulut, A.; Baran, Y. Molecular mechanisms of drug resistance and its reversal in cancer. Crit. Rev. Biotechnol. 2016, 36, 716-726. [CrossRef] [PubMed]

68. Sauerbrey, A.; Sell, W.; Steinbach, D.; Voigt, A.; Zintl, F. Expression of the BCRP gene (ABCG2/MXR/ABCP) in childhood acute lymphoblastic leukaemia. Br. J. Haematol. 2002, 118, 147-150. [CrossRef]

69. Washio, I.; Nakanishi, T.; Ishiguro, N.; Yamamura, N.; Tamai, I. Impact of Breast Cancer Resistance Protein Expression on the In Vitro Efficacy of Anticancer Drugs in Pancreatic Cancer Cell Lines. Drug Metab. Dispos. 2018, 46, 214-222. [CrossRef] [PubMed]

70. Chen, M.; Liang, X.; Gao, C.; Zhao, R.; Zhang, N.; Wang, S.; Chen, W.; Zhao, B.; Wang, J.; Dai, Z. Ultrasound Triggered Conversion of Porphyrin/Camptothecin-Fluoroxyuridine Triad Microbubbles into Nanoparticles Overcomes Multidrug Resistance in Colorectal Cancer. ACS Nano. 2018, 12, 7312-7326. [CrossRef]

71. Keppler, D. The roles of MRP2, MRP3, OATP1B1, and OATP1B3 in conjugated hyperbilirubinemia. Drug Metab. Dispos. 2014, 42, 561-565. [CrossRef]

72. Kruh, G.D.; Belinsky, M.G. The MRP family of drug efflux pumps. Oncogene 2003, 22, 7537-7552. [CrossRef]

73. Ozben, T. Mechanisms and strategies to overcome multiple drug resistance in cancer. FEBS Lett. 2006, 580, 2903-2909. [CrossRef]

74. Sodani, K.; Patel, A.; Kathawala, R.J.; Chen, Z.S. Multidrug resistance associated proteins in multidrug resistance. Chin. J. Cancer 2012, 31, 58-72. [CrossRef] [PubMed]

75. Leonard, G.D.; Fojo, T.; Bates, S.E. The role of ABC transporters in clinical practice. Oncologist 2003, 8, 411-424. [CrossRef]

76. Gottesman, M.M.; Lavi, O.; Hall, M.D.; Gillet, J.P. Toward a Better Understanding of the Complexity of Cancer Drug Resistance. Annu. Rev. Pharm. Toxicol. 2016, 56, 85-102. [CrossRef]

77. Sigismund, S.; Avanzato, D.; Lanzetti, L. Emerging functions of the EGFR in cancer. Mol. Oncol. 2018, 12, 3-20. [CrossRef]

78. Ciardiello, F.; Tortora, G. Epidermal growth factor receptor (EGFR) as a target in cancer therapy: Understanding the role of receptor expression and other molecular determinants that could influence the response to anti-EGFR drugs. Eur. J. Cancer 2003, 39, 1348-1354. [CrossRef]

79. Yamaoka, T.; Ohba, M.; Ohmori, T. Molecular-Targeted Therapies for Epidermal Growth Factor Receptor and Its Resistance Mechanisms. Int. J. Mol. Sci. 2017, 18, 2420. [CrossRef]

80. Wykosky, J.; Fenton, T.; Furnari, F.; Cavenee, W.K. Therapeutic targeting of epidermal growth factor receptor in human cancer: Successes and limitations. Chin. J. Cancer 2011, 30, 5-12. [CrossRef] [PubMed]

81. Blasco, M.T.; Navas, C.; Martin-Serrano, G.; Grana-Castro, O.; Lechuga, C.G.; Martin-Diaz, L.; Djurec, M.; Li, J.; Morales-Cacho, L.; Esteban-Burgos, L.; et al. Complete Regression of Advanced Pancreatic Ductal Adenocarcinomas upon Combined Inhibition of EGFR and C-RAF. Cancer Cell 2019, 35, 573-587. [CrossRef]

82. Chong, C.R.; Janne, P.A. The quest to overcome resistance to EGFR-targeted therapies in cancer. Nat. Med. 2013, 19, 1389-1400. [CrossRef]

83. Fitzgerald, T.L.; Lertpiriyapong, K.; Cocco, L.; Martelli, A.M.; Libra, M.; Candido, S.; Montalto, G.; Cervello, M.; Steelman, L.; Abrams, S.L.; et al. Roles of EGFR and KRAS and their downstream signaling pathways in pancreatic cancer and pancreatic cancer stem cells. Adv. Biol. Regul. 2015, 59, 65-81. [CrossRef]

84. Van Emburgh, B.O.; Arena, S.; Siravegna, G.; Lazzari, L.; Crisafulli, G.; Corti, G.; Mussolin, B.; Baldi, F.; Buscarino, M.; Bartolini, A.; et al. Acquired RAS or EGFR mutations and duration of response to EGFR blockade in colorectal cancer. Nat. Commun. 2016, 7, 13665. [CrossRef]

85. Khan, J.A.; Kudgus, R.A.; Szabolcs, A.; Dutta, S.; Wang, E.; Cao, S.; Curran, G.L.; Shah, V.; Curley, S.; Mukhopadhyay, D.; et al. Designing nanoconjugates to effectively target pancreatic cancer cells in vitro and in vivo. PLoS ONE 2011, 6, e20347. [CrossRef]

86. McDaid, W.J.; Greene, M.K.; Johnston, M.C.; Pollheimer, E.; Smyth, P.; McLaughlin, K.; Van Schaeybroeck, S.; Straubinger, R.M.; Longley, D.B.; Scott, C.J. Repurposing of Cetuximab in antibody-directed chemotherapy-loaded nanoparticles in EGFR therapy-resistant pancreatic tumours. Nanoscale 2019, 11, 20261-20273. [CrossRef]

87. Santos-Rebelo, A.; Kumar, P.; Pillay, V.; Choonara, Y.E.; Eleuterio, C.; Figueira, M.; Viana, A.S.; Ascensao, L.; Molpeceres, J.; Rijo, P.; et al. Development and Mechanistic Insight into the Enhanced Cytotoxic Potential of Parvifloron D Albumin Nanoparticles in EGFR-Overexpressing Pancreatic Cancer Cells. Cancers 2019, 11, 1733. [CrossRef]

88. Liszbinski, R.B.; Romagnoli, G.G.; Gorgulho, C.M.; Basso, C.R.; Pedrosa, V.A.; Kaneno, R. Anti-EGFR-Coated Gold Nanoparticles In Vitro Carry 5-Fluorouracil to Colorectal Cancer Cells. Materials 2020, 13, 375. [CrossRef] [PubMed]

89. Leve, F.; Bonfim, D.P.; Fontes, G.; Morgado-Diaz, J.A. Gold nanoparticles regulate tight junctions and improve cetuximab effect in colon cancer cells. Nanomedicine 2019, 14, 1565-1578. [CrossRef]

90. Du, C.; Qi, Y.; Zhang, Y.; Wang, Y.; Zhao, X.; Min, H.; Han, X.; Lang, J.; Qin, H.; Shi, Q.; et al. Epidermal Growth Factor Receptor-Targeting Peptide Nanoparticles Simultaneously Deliver Gemcitabine and Olaparib To Treat Pancreatic Cancer with Breast Cancer 2 (BRCA2) Mutation. Acs. Nano. 2018, 12, 10785-10796. [CrossRef] 
91. Singh, A.; Xu, J.; Mattheolabakis, G.; Amiji, M. EGFR-targeted gelatin nanoparticles for systemic administration of gemcitabine in an orthotopic pancreatic cancer model. Nanomedicine 2016, 12, 589-600. [CrossRef] [PubMed]

92. Li, C.; Cai, G.; Song, D.; Gao, R.; Teng, P.; Zhou, L.; Ji, Q.; Sui, H.; Cai, J.; Li, Q.; et al. Development of EGFR-targeted evodiamine nanoparticles for the treatment of colorectal cancer. Biomater. Sci. 2019, 7, 3627-3639. [CrossRef]

93. Leng, A.; Yang, J.; Liu, T.; Cui, J.; Li, X.H.; Zhu, Y.; Xiong, T.; Chen, Y. Nanoparticle-delivered VEGF-silencing cassette and suicide gene expression cassettes inhibit colon carcinoma growth in vitro and in vivo. Tumour. Biol. 2011, 32, 1103-1111. [CrossRef]

94. Lee, S.Y.; Yang, C.Y.; Peng, C.L.; Wei, M.F.; Chen, K.C.; Yao, C.J.; Shieh, M.J. A theranostic micelleplex co-delivering SN-38 and VEGF siRNA for colorectal cancer therapy. Biomaterials 2016, 86, 92-105. [CrossRef]

95. Mirza-Aghazadeh-Attari, M.; Darband, S.G.; Kaviani, M.; Mihanfar, A.; Aghazadeh Attari, J.; Yousefi, B.; Majidinia, M. DNA damage response and repair in colorectal cancer: Defects, regulation and therapeutic implications. DNA Repair. 2018, 69, 34-52. [CrossRef]

96. Motegi, A.; Masutani, M.; Yoshioka, K.i.; Bessho, T. Aberrations in DNA repair pathways in cancer and therapeutic significances. Semin. Cancer Biol. 2019, 58, 29-46. [CrossRef]

97. Chaudhuri, A.R.; Nussenzweig, A. The multifaceted roles of PARP1 in DNA repair and chromatin remodelling. Nat. Rev. Mol. Cell Biol. 2017, 18, 610-621. [CrossRef]

98. Liu, H.; Zhang, Z.; Chi, X.; Zhao, Z.; Huang, D.; Jin, J.; Gao, J. Arsenite-loaded nanoparticles inhibit PARP-1 to overcome multidrug resistance in hepatocellular carcinoma cells. Sci. Rep. 2016, 6, 31009. [CrossRef]

99. Van De Ven, A.L.; Tangutoori, S.; Baldwin, P.; Qiao, J.; Gharagouzloo, C.; Seitzer, N.; Clohessy, J.G.; Makrigiorgos, G.M.; Cormack, R.; Pandolfi, P.P.; et al. Nanoformulation of olaparib amplifies PARP inhibition and sensitizes PTEN/TP53-deficient prostate cancer to radiation. Mol. Cancer Ther. 2017, 16, 1279-1289. [CrossRef]

100. Mensah, L.B.; Morton, S.W.; Li, J.; Xiao, H.; Quadir, M.A.; Elias, K.M.; Penn, E.; Richson, A.K.; Ghoroghchian, P.P.; Liu, J.; et al Layer-by-layer nanoparticles for novel delivery of cisplatin and PARP inhibitors for platinum-based drug resistance therapy in ovarian cancer. Bioeng. Transl. Med. 2019, 4, e10131. [CrossRef] [PubMed]

101. Zhang, D.; Baldwin, P.; Leal, A.S.; Carapellucci, S.; Sridhar, S.; Liby, K.T. A nano-liposome formulation of the PARP inhibitor talazoparib enhances treatment efficacy and modulates immune cell populations in mammary tumors of BRCA-deficient mice. Theranostics 2019, 9, 6224-6238. [CrossRef]

102. Guney Eskiler, G.; Cecener, G.; Egeli, U.; Tunca, B. Synthetically Lethal BMN 673 (Talazoparib) Loaded Solid Lipid Nanoparticles for BRCA1 Mutant Triple Negative Breast Cancer. Pharm. Res. 2018, 35, 218. [CrossRef]

103. Kamel, D.; Gray, C.; Walia, J.S.; Kumar, V. PARP Inhibitor Drugs in the Treatment of Breast, Ovarian, Prostate and Pancreatic Cancers: An Update of Clinical Trials. Curr. Drug Targets 2018, 19, 21-37. [CrossRef]

104. Leichman, L.; Groshen, S.; O’Neil, B.H.; Messersmith, W.; Berlin, J.; Chan, E.; Leichman, C.G.; Cohen, S.J.; Cohen, D.; Lenz, H.J.; et al. Phase II Study of Olaparib (AZD-2281) After Standard Systemic Therapies for Disseminated Colorectal Cancer. Oncol. 2016, 21, 172-177. [CrossRef]

105. Baretti, M.; Le, D.T. DNA mismatch repair in cancer. Pharmacol. Ther. 2018, 189, 45-62. [CrossRef]

106. Chatterjee, N.; Walker, G.C. Mechanisms of DNA damage, repair, and mutagenesis. Environ. Mol. Mutagenesis 2017, 58, 235-263. [CrossRef]

107. Sehdev, A.; Gbolahan, O.; Hancock, B.A.; Stanley, M.; Shahda, S.; Wan, J.; Wu, H.H.; Radovich, M.; O'Neil, B.H. Germline and somatic DNA damage repair gene mutations and overall survival in metastatic pancreatic adenocarcinoma patients treated with FOLFIRINOX. Clin. Cancer Res. 2018, 24, 6204-6211. [CrossRef]

108. Li, S.K.H.; Martin, A. Mismatch Repair and Colon Cancer: Mechanisms and Therapies Explored. Trends Mol. Med. 2016, 22, 274-289. [CrossRef]

109. Tentori, L.; Leonetti, C.; Muzi, A.; Dorio, A.S.; Porru, M.; Dolci, S.; Campolo, F.; Vernole, P.; Lacal, P.M.; Praz, F.; et al. Influence of MLH1 on colon cancer sensitivity to poly(ADP-ribose) polymerase inhibitor combined with irinotecan. Int. J. Oncol. 2013, 43, 210-218. [CrossRef]

110. AshaRani, P.V.; Sethu, S.; Lim, H.K.; Balaji, G.; Valiyaveettil, S.; Hande, M.P. Differential regulation of intracellular factors mediating cell cycle, DNA repair and inflammation following exposure to silver nanoparticles in human cells. Genome. Integr. 2012, 3, 2. [CrossRef]

111. Sun, Y.; Peng, Z.L. Programmed cell death and cancer. Postgrad. Med. J. 2009, 85, 134-140. [CrossRef]

112. Pfeffer, C.M.; Singh, A.T.K. Apoptosis: A Target for Anticancer Therapy. Int. J. Mol. Sci. 2018, 19, 448. [CrossRef]

113. Baghbani-Arani, F.; Movagharnia, R.; Sharifian, A.; Salehi, S.; Shandiz, S.A.S. Photo-catalytic, anti-bacterial, and anti-cancer properties of phyto-mediated synthesis of silver nanoparticles from Artemisia tournefortiana Rchb extract. J. Photochem. Photobiol. B 2017, 173, 640-649. [CrossRef]

114. Gopinath, P.; Gogoi, S.K.; Sanpui, P.; Paul, A.; Chattopadhyay, A.; Ghosh, S.S. Signaling gene cascade in silver nanoparticle induced apoptosis. Colloids. Surf. B Biointerfaces 2010, 77, 240-245. [CrossRef]

115. Nehal, M.E.; Ibrahim, M.E.; Mohamed, R.E.; Elsayed, E.H. Novel Trend in Colon Cancer Therapy Using Silver Nanoparticles Synthesized by Honey Bee. J. Nanomed. Nanotechnol. 2015, 6, 1000265. [CrossRef]

116. Jia, M.; Zhang, W.; He, T.; Shu, M.; Deng, J.; Wang, J.; Li, W.; Bai, J.; Lin, Q.; Luo, F.; et al. Evaluation of the Genotoxic and Oxidative Damage Potential of Silver Nanoparticles in Human NCM460 and HCT116 Cells. Int. J. Mol. Sci. 2020, $21,1618$. [CrossRef] 
117. Satapathy, S.R.; Mohapatra, P.; Preet, R.; Das, D.; Sarkar, B.; Choudhuri, T.; Wyatt, M.D.; Kundu, C.N. Silver-based nanoparticles induce apoptosis in human colon cancer cells mediated through p53. Nanomedicine 2013, 8, 1307-1322. [CrossRef] [PubMed]

118. Zielinska, E.; Zauszkiewicz-Pawlak, A.; Wojcik, M.; Inkielewicz-Stepniak, I. Silver nanoparticles of different sizes induce a mixed type of programmed cell death in human pancreatic ductal adenocarcinoma. Oncotarget 2018, 9, 4675-4697. [CrossRef]

119. Huang, R.-F.S.; Wei, Y.; Inbaraj, B.S.; Chen, B.-H. Inhibition of colon cancer cell growth by nanoemulsion carrying gold nanoparticles and lycopene. Int. J. Nanomed. 2015, 10, 2823-2846. [CrossRef]

120. Huang, W.; Liu, Z.; Zhou, G.; Tian, A.; Sun, N. Magnetic gold nanoparticle-mediated small interference RNA silencing Bag-1 gene for colon cancer therapy. Oncol. Rep. 2016, 35, 978-984. [CrossRef]

121. Khan, S.; Ansari, A.A.; Khan, A.A.; Abdulla, M.; Al-Obaid, O.; Ahmad, R. In vitro evaluation of cytotoxicity, possible alteration of apoptotic regulatory proteins, and antibacterial activity of synthesized copper oxide nanoparticles. Colloids. Surf. B Biointerfaces 2017, 153, 320-326. [CrossRef]

122. Liu, Z.; Xiong, L.; Ouyang, G.; Ma, L.; Sahi, S.; Wang, K.; Lin, L.; Huang, H.; Miao, X.; Chen, W.; et al. Investigation of Copper Cysteamine Nanoparticles as a New Type of Radiosensitiers for Colorectal Carcinoma Treatment. Sci. Rep. 2017, 7, 9290. [CrossRef]

123. Qian, C.; Wang, Y.; Chen, Y.; Zeng, L.; Zhang, Q.; Shuai, X.; Huang, K. Suppression of pancreatic tumor growth by targeted arsenic delivery with anti-CD44v6 single chain antibody conjugated nanoparticles. Biomaterials 2013, 34, 6175-6184. [CrossRef] [PubMed]

124. Yassin, A.M.; Elnouby, M.; El-Deeb, N.M.; Hafez, E.E. Tungsten Oxide Nanoplates; the Novelty in Targeting Metalloproteinase-7 Gene in Both Cervix and Colon Cancer Cells. Appl. Biochem. Biotechnol. 2016, 180, 623-637. [CrossRef]

125. Motawi, T.K.; El-Maraghy, S.A.; ElMeshad, A.N.; Nady, O.M.; Hammam, O.A. Cromolyn chitosan nanoparticles as a novel protective approach for colorectal cancer. Chem. Biol. Interact. 2017, 275, 1-12. [CrossRef]

126. Ravi, H.; Kurrey, N.; Manabe, Y.; Sugawara, T.; Baskaran, V. Polymeric chitosan-glycolipid nanocarriers for an effective delivery of marine carotenoid fucoxanthin for induction of apoptosis in human colon cancer cells (Caco-2 cells). Mater. Sci. Eng. C Mater. Biol. Appl. 2018, 91, 785-795. [CrossRef]

127. Wang, C.; Zhang, H.; Chen, B.; Yin, H.; Wang, W. Study of the enhanced anticancer efficacy of gambogic acid on Capan-1 pancreatic cancer cells when mediated via magnetic Fe3O4 nanoparticles. Int. J. Nanomed. 2011, 6, 1929-1935. [CrossRef]

128. Yallapu, M.M.; Ebeling, M.C.; Khan, S.; Sundram, V.; Chauhan, N.; Gupta, B.K.; Puumala, S.E.; Jaggi, M.; Chauhan, S.C. Novel curcumin-loaded magnetic nanoparticles for pancreatic cancer treatment. Mol. Cancer Ther. 2013, 12, 1471-1480. [CrossRef]

129. Tang, Y.T.; Xu, X.H.; Yang, X.D.; Hao, J.; Cao, H.; Zhu, W.; Zhang, S.Y.; Cao, J.P. Role of non-coding RNAs in pancreatic cancer: The bane of the microworld. World J. Gastroenterol. 2014, 20, 9405-9417. [CrossRef]

130. Duguang, L.; Jin, H.; Xiaowei, Q.; Peng, X.; Xiaodong, W.; Zhennan, L.; Jianjun, Q.; Jie, Y. The involvement of lncRNAs in the development and progression of pancreatic cancer. Cancer Biol. Ther. 2017, 18, 927-936. [CrossRef] [PubMed]

131. Zhu, J.; Zhang, R.; Yang, D.; Li, J.; Yan, X.; Jin, K.; Li, W.; Liu, X.; Zhao, J.; Shang, W.; et al. Knockdown of Long Non-Coding RNA XIST Inhibited Doxorubicin Resistance in Colorectal Cancer by Upregulation of miR-124 and Downregulation of SGK1. Cell Physiol. Biochem. 2018, 51, 113-128. [CrossRef]

132. Bian, Z.; Jin, L.; Zhang, J.; Yin, Y.; Quan, C.; Hu, Y.; Feng, Y.; Liu, H.; Fei, B.; Mao, Y.; et al. LncRNA-UCA1 enhances cell proliferation and 5-fluorouracil resistance in colorectal cancer by inhibiting miR-204-5p. Sci. Rep. 2016, 6, 23892. [CrossRef]

133. Gao, R.; Fang, C.; Xu, J.; Tan, H.; Li, P.; Ma, L. LncRNA CACS15 contributes to oxaliplatin resistance in colorectal cancer by positively regulating ABCC1 through sponging miR-145. Arch. Biochem. Biophys. 2019, 663, 183-191. [CrossRef]

134. Si, W.; Shen, J.; Zheng, H.; Fan, W. The role and mechanisms of action of microRNAs in cancer drug resistance. Clin. Epigenetics. 2019, 11, 25. [CrossRef] [PubMed]

135. Jin, G.; Liu, Y.; Zhang, J.; Bian, Z.; Yao, S.; Fei, B.; Zhou, L.; Yin, Y.; Huang, Z. A panel of serum exosomal microRNAs as predictive markers for chemoresistance in advanced colorectal cancer. Cancer Chemother. Pharm. 2019, 84, 315-325. [CrossRef] [PubMed]

136. Xu, F.; Ye, M.L.; Zhang, Y.P.; Li, W.J.; Li, M.T.; Wang, H.Z.; Qiu, X.; Xu, Y.; Yin, J.W.; Hu, Q.; et al. MicroRNA-375-3p enhances chemosensitivity to 5-fluorouracil by targeting thymidylate synthase in colorectal cancer. Cancer Sci. 2020, 111, $1528-1541$. [CrossRef] [PubMed]

137. Juang, V.; Chang, C.H.; Wang, C.S.; Wang, H.E.; Lo, Y.L. pH-Responsive PEG-Shedding and Targeting Peptide-Modified Nanoparticles for Dual-Delivery of Irinotecan and microRNA to Enhance Tumor-Specific Therapy. Small 2019, 15, e1903296. [CrossRef]

138. Yang, H.; Liu, Y.; Qiu, Y.; Ding, M.; Zhang, Y. MiRNA-204-5p and oxaliplatin-loaded silica nanoparticles for enhanced tumor suppression effect in CD44-overexpressed colon adenocarcinoma. Int. J. Pharm. 2019, 566, 585-593. [CrossRef]

139. Zheng, B.; Chen, L.; Pan, C.C.; Wang, J.Z.; Lu, G.R.; Yang, S.X.; Xue, Z.X.; Wang, F.Y.; Xu, C.L. Targeted delivery of miRNA-204-5p by PEGylated polymer nanoparticles for colon cancer therapy. Nanomedicine 2018, 13, 769-785. [CrossRef]

140. Liang, G.; Zhu, Y.; Jing, A.; Wang, J.; Hu, F.; Feng, W.; Xiao, Z.; Chen, B. Cationic microRNA-delivering nanocarriers for efficient treatment of colon carcinoma in xenograft model. Gene Ther. 2016, 23, 829-838. [CrossRef]

141. Hong, S.T.; Lin, H.; Wang, C.S.; Chang, C.H.; Lin, A.M.; Yang, J.C.; Lo, Y.L. Improving the anticancer effect of afatinib and microRNA by using lipid polymeric nanoparticles conjugated with dual $\mathrm{pH}$-responsive and targeting peptides. J. Nanobiotechnology 2019, 17, 89. [CrossRef] 
142. Lukowski, S.; Neuhoferova, E.; Kinderman, M.; Krivohlava, R.; Mineva, A.; Petrakova, V.; Benson, V. Fluorescent Nanodiamonds are Efficient, Easy-to-Use Cyto-Compatible Vehicles for Monitored Delivery of Non-Coding Regulatory RNAs. J. Biomed. Nanotechnol. 2018, 14, 946-958. [CrossRef] [PubMed]

143. Li, Y.; Duo, Y.; Bi, J.; Zeng, X.; Mei, L.; Bao, S.; He, L.; Shan, A.; Zhang, Y.; Yu, X. Targeted delivery of anti-miR-155 by functionalized mesoporous silica nanoparticles for colorectal cancer therapy. Int. J. Nanomed. 2018, 13, 1241-1256. [CrossRef]

144. Arora, S.; Swaminathan, S.K.; Kirtane, A.; Srivastava, S.K.; Bhardwaj, A.; Singh, S.; Panyam, J.; Singh, A.P. Synthesis, characterization, and evaluation of poly (D,L-lactide-co-glycolide)-based nanoformulation of miRNA-150: Potential implications for pancreatic cancer therapy. Int. J. Nanomed. 2014, 9, 2933-2942. [CrossRef]

145. Setua, S.; Khan, S.; Yallapu, M.M.; Behrman, S.W.; Sikander, M.; Khan, S.S.; Jaggi, M.; Chauhan, S.C. Restitution of Tumor Suppressor MicroRNA-145 Using Magnetic Nanoformulation for Pancreatic Cancer Therapy. J. Gastrointest. Surg. 2017, 21, 94-105. [CrossRef] [PubMed]

146. Ferino, A.; Miglietta, G.; Picco, R.; Vogel, S.; Wengel, J.; Xodo, L.E. MicroRNA therapeutics: Design of single-stranded miR-216b mimics to target KRAS in pancreatic cancer cells. RNA Biol. 2018, 15, 1273-1285. [CrossRef]

147. Chen, W.; Zhou, Y.; Zhi, X.; Ma, T.; Liu, H.; Chen, B.W.; Zheng, X.; Xie, S.; Zhao, B.; Feng, X.; et al. Delivery of miR-212 by chimeric peptide-condensed supramolecular nanoparticles enhances the sensitivity of pancreatic ductal adenocarcinoma to doxorubicin. Biomaterials 2019, 192, 590-600. [CrossRef]

148. Wu, Y.; Tang, Y.; Xie, S.; Zheng, X.; Zhang, S.; Mao, J.; Wang, B.; Hou, Y.; Hu, L.; Chai, K.; et al. Chimeric peptide supramolecular nanoparticles for plectin-1 targeted miRNA-9 delivery in pancreatic cancer. Theranostics 2020, 10, 1151-1165. [CrossRef] [PubMed]

149. Mokhlis, H.A.; Bayraktar, R.; Kabil, N.N.; Caner, A.; Kahraman, N.; Rodriguez-Aguayo, C.; Zambalde, E.P.; Sheng, J.; Karagoz, K.; Kanlikilicer, P.; et al. The Modulatory Role of MicroRNA-873 in the Progression of KRAS-Driven Cancers. Mol. Ther. Nucleic. Acids 2019, 14, 301-317. [CrossRef] [PubMed]

150. Gokita, K.; Inoue, J.; Ishihara, H.; Kojima, K.; Inazawa, J. Therapeutic Potential of LNP-Mediated Delivery of miR-634 for Cancer Therapy. Mol. Ther.Nucleic. Acids 2020, 19, 330-338. [CrossRef]

151. Xie, Y.; Hang, Y.; Wang, Y.; Sleightholm, R.; Prajapati, D.R.; Bader, J.; Yu, A.; Tang, W.; Jaramillo, L.; Li, J.; et al. Stromal Modulation and Treatment of Metastatic Pancreatic Cancer with Local Intraperitoneal Triple miRNA/siRNA Nanotherapy. Acs. Nano. 2020, 14, 255-271. [CrossRef]

152. Li, Y.; Chen, Y.; Li, J.; Zhang, Z.; Huang, C.; Lian, G.; Yang, K.; Chen, S.; Lin, Y.; Wang, L.; et al. Co-delivery of microRNA-21 antisense oligonucleotides and gemcitabine using nanomedicine for pancreatic cancer therapy. Cancer Sci. 2017, 108, 1493-1503. [CrossRef]

153. Gilles, M.E.; Hao, L.; Brown, K.; Lim, J.; Bhatia, S.N.; Slack, F.J. Tumor penetrating nanomedicine targeting both an oncomiR and an oncogene in pancreatic cancer. Oncotarget 2019, 10, 5349-5358. [CrossRef] [PubMed]

154. Xie, Z.; Liu, W.; Huang, H.; Slavin, M.; Zhao, Y.; Whent, M.; Blackford, J.; Lutterodt, H.; Zhou, H.; Chen, P.; et al. Chemical Composition of Five Commercial Gynostemma pentaphyllum Samples and Their Radical Scavenging, Antiproliferative, and Anti-inflammatory Properties. J. Agric. Food Chem. 2010, 58, 11243-11249. [CrossRef] [PubMed]

155. Tse, J.W.T.; Jenkins, L.J.; Chionh, F.; Mariadason, J.M. Aberrant DNA Methylation in Colorectal Cancer: What Should We Target? Trends. Cancer 2017, 3, 698-712. [CrossRef] [PubMed]

156. Grant, T.J.; Hua, K.; Singh, A. Molecular Pathogenesis of Pancreatic Cancer. Prog. Mol. Biol. Transl. Sci. 2016, 144, 241-275. [CrossRef]

157. Neureiter, D.; Jäger, T.; Ocker, M.; Kiesslich, T. Epigenetics and pancreatic cancer: Pathophysiology and novel treatment aspects. World J. Gastroenterol. 2014, 20, 7830-7848. [CrossRef] [PubMed]

158. Patnaik, S.; Anupriya. Drugs targeting epigenetic modifications and plausible therapeutic strategies against colorectal cancer. Front. Pharmacol. 2019, 10, 588. [CrossRef]

159. Shen, Y.; Tong, M.; Liang, Q.; Guo, Y.; Sun, H.Q.; Zheng, W.; Ao, L.; Guo, Z.; She, F. Epigenomics alternations and dynamic transcriptional changes in responses to 5-fluorouracil stimulation reveal mechanisms of acquired drug resistance of colorectal cancer cells. Pharm. J. 2018, 18, 23-28. [CrossRef]

160. Liu, T.; Wang, X.; Hu, W.; Fang, Z.; Jin, Y.; Fang, X.; Miao, Q.R. Epigenetically Down-Regulated Acetyltransferase PCAF Increases the Resistance of Colorectal Cancer to 5-Fluorouracil. Neoplasia 2019, 21, 557-570. [CrossRef]

161. Hsu, M.C.; Pan, M.R.; Chu, P.Y.; Tsai, Y.L.; Tsai, C.H.; Shan, Y.S.; Chen, L.T.; Hung, W.C. Protein Arginine Methyltransferase 3 Enhances Chemoresistance in Pancreatic Cancer by Methylating hnRNPA1 to Increase ABCG2 Expression. Cancers 2018, 11, 8. [CrossRef] [PubMed]

162. Pan, Y.; Wang, L.; Kang, S.G.; Lu, Y.; Yang, Z.; Huynh, T.; Chen, C.; Zhou, R.; Guo, M.; Zhao, Y. Gd-Metallofullerenol Nanomaterial Suppresses Pancreatic Cancer Metastasis by Inhibiting the Interaction of Histone Deacetylase 1 and Metastasis-Associated Protein 1. ACS Nano. 2015, 9, 6826-6836. [CrossRef] [PubMed]

163. Lindemann, H.; Kuhne, M.; Grune, C.; Warncke, P.; Hofmann, S.; Koschella, A.; Godmann, M.; Fischer, D.; Heinzel, T.; Heinze, T. Polysaccharide Nanoparticles Bearing HDAC Inhibitor as Nontoxic Nanocarrier for Drug Delivery. Macromol. Biosci. 2020, 20, e2000039. [CrossRef] [PubMed]

164. Wang, E.C.; Min, Y.; Palm, R.C.; Fiordalisi, J.J.; Wagner, K.T.; Hyder, N.; Cox, A.D.; Caster, J.M.; Tian, X.; Wang, A.Z. Nanoparticle formulations of histone deacetylase inhibitors for effective chemoradiotherapy in solid tumors. Biomaterials 2015, 51, 208-215. [CrossRef] 
165. Kularatne, R.N.; Washington, K.E.; Bulumulla, C.; Calubaquib, E.L.; Biewer, M.C.; Oupicky, D.; Stefan, M.C. Histone Deacetylase Inhibitor (HDACi) Conjugated Polycaprolactone for Combination Cancer Therapy. Biomacromolecules 2018, 19, 1082-1089. [CrossRef]

166. Busi, A.; Aluigi, A.; Guerrini, A.; Boga, C.; Sartor, G.; Calonghi, N.; Sotgiu, G.; Posati, T.; Corticelli, F.; Fiori, J.; et al. Unprecedented Behavior of (9 R)-9-Hydroxystearic Acid-Loaded Keratin Nanoparticles on Cancer Cell Cycle. Mol. Pharm. 2019, 16, 931-942. [CrossRef]

167. Prieto-Vila, M.; Takahashi, R.U.; Usuba, W.; Kohama, I.; Ochiya, T. Drug Resistance Driven by Cancer Stem Cells and Their Niche. Int. J. Mol. Sci. 2017, 18, 2574. [CrossRef]

168. Pedrosa, L.; Esposito, F.; Thomson, T.M.; Maurel, J. The Tumor Microenvironment in Colorectal Cancer Therapy. Cancers 2019, 11, 1172. [CrossRef]

169. Roma-Rodrigues, C.; Mendes, R.; Baptista, P.V.; Fernandes, A.R. Targeting Tumor Microenvironment for Cancer Therapy. Int. J. Mol. Sci. 2019, 20, 840. [CrossRef] [PubMed]

170. Chakraborty, C.; Sharma, A.R.; Sharma, G.; Lee, S.S. The Interplay among miRNAs, Major Cytokines, and Cancer-Related Inflammation. Mol. Ther. Nucleic. Acids. 2020, 20, 606-620. [CrossRef]

171. Eble, J.A.; Niland, S. The extracellular matrix in tumor progression and metastasis. Clin. Exp. Metastasis 2019, 36, 171-198. [CrossRef]

172. Javan, B.; Atyabi, F.; Shahbazi, M. Hypoxia-inducible bidirectional shRNA expression vector delivery using PEI/chitosan-TBA copolymers for colorectal Cancer gene therapy. Life Sci. 2018, 202, 140-151. [CrossRef]

173. Meng, L.; Cheng, Y.; Gan, S.; Zhang, Z.; Tong, X.; Xu, L.; Jiang, X.; Zhu, Y.; Wu, J.; Yuan, A.; et al. Facile Deposition of Manganese Dioxide to Albumin-Bound Paclitaxel Nanoparticles for Modulation of Hypoxic Tumor Microenvironment To Improve Chemoradiation Therapy. Mol. Pharm. 2018, 15, 447-457. [CrossRef] [PubMed]

174. He, H.; Liu, L.; Liang, R.; Zhou, H.; Pan, H.; Zhang, S.; Cai, L. Tumor-targeted nanoplatform for in situ oxygenation-boosted immunogenic phototherapy of colorectal cancer. ACTA Biomater. 2020, 104, 188-197. [CrossRef]

175. Aljabali, A.A.A.; Bakshi, H.A.; Hakkim, F.L.; Haggag, Y.A.; Al-Batanyeh, K.M.; Al Zoubi, M.S.; Al-Trad, B.; Nasef, M.M.; Satija, S.; Mehta, M.; et al. Albumin Nano-Encapsulation of Piceatannol Enhances Its Anticancer Potential in Colon Cancer Via Downregulation of Nuclear p65 and HIF-1alpha. Cancers 2020, 12, 113. [CrossRef]

176. Kulkarni, P.; Haldar, M.K.; Karandish, F.; Confeld, M.; Hossain, R.; Borowicz, P.; Gange, K.; Xia, L.; Sarkar, K.; Mallik, S. Tissue-Penetrating, Hypoxia-Responsive Echogenic Polymersomes For Drug Delivery To Solid Tumors. Chemistry 2018, 24, 12490-12494. [CrossRef] [PubMed]

177. Chen, J.; Luo, H.; Liu, Y.; Zhang, W.; Li, H.; Luo, T.; Zhang, K.; Zhao, Y.; Liu, J. Oxygen-Self-Produced Nanoplatform for Relieving Hypoxia and Breaking Resistance to Sonodynamic Treatment of Pancreatic Cancer. ACS Nano. 2017, 11, 12849-12862. [CrossRef] [PubMed]

178. Liu, Y.; Wen, Y.; Chen, X.; Zhu, X.; Yu, Q.; Gong, Y.; Yuan, G.; Liu, J.; Qin, X. Inflammation-responsive functional Ru nanoparticles combining a tumor-associated macrophage repolarization strategy with phototherapy for colorectal cancer therapy. J. Mater. Chem. B 2019, 7, 6210-6223. [CrossRef] [PubMed]

179. Cao, D.; Liang, L.; Xu, Y.; Sun, J.; Lei, M.; Wang, M.; Wei, Y.; Sun, Z. Tumor associated macrophages and angiogenesis dual-recognizable nanoparticles for enhanced cancer chemotherapy. Nanomedicine 2018, 14, 651-659. [CrossRef]

180. Han, X.; Li, Y.; Xu, Y.; Zhao, X.; Zhang, Y.; Yang, X.; Wang, Y.; Zhao, R.; Anderson, G.J.; Zhao, Y.; et al. Reversal of pancreatic desmoplasia by re-educating stellate cells with a tumour microenvironment-activated nanosystem. Nat. Commun. 2018, 9, 3390. [CrossRef]

181. Smith, A.G.; Macleod, K.F. Autophagy, cancer stem cells and drug resistance. J. Pathol. 2019, 247, 708-718. [CrossRef]

182. Debele, T.A.; Yu, L.Y.; Yang, C.S.; Shen, Y.A.; Lo, C.L. pH- and GSH-Sensitive Hyaluronic Acid-MP Conjugate Micelles for Intracellular Delivery of Doxorubicin to Colon Cancer Cells and Cancer Stem Cells. Biomacromolecules 2018, 19, 3725-3737. [CrossRef]

183. Li, L.; Li, X.; Wu, Y.; Song, L.; Yang, X.; He, T.; Wang, N.; Yang, S.; Zeng, Y.; Wu, Q.; et al. Multifunctional Nucleus-targeting Nanoparticles with Ultra-high Gene Transfection Efficiency for In Vivo Gene Therapy. Theranostics 2017, 7, 1633-1649. [CrossRef]

184. Zahiri, M.; Babaei, M.; Abnous, K.; Taghdisi, S.M.; Ramezani, M.; Alibolandi, M. Hybrid nanoreservoirs based on dextran-capped dendritic mesoporous silica nanoparticles for CD133-targeted drug delivery. J. Cell. Physiol. 2020, 235, 1036-1050. [CrossRef]

185. Serna, N.; Alamo, P.; Ramesh, P.; Vinokurova, D.; Sanchez-Garcia, L.; Unzueta, U.; Gallardo, A.; Cespedes, M.V.; Vazquez, E.; Villaverde, A.; et al. Nanostructured toxins for the selective destruction of drug-resistant human CXCR4(+) colorectal cancer stem cells. J. Control. Release. 2020, 320, 96-104. [CrossRef] [PubMed]

186. Montero, S.; Seras-Franzoso, J.; Andrade, F.; Martinez-Trucharte, F.; Vilar-Hernandez, M.; Quesada, M.; Xandri, H.; Arango, D.; Abasolo, I.; Rafael, D.; et al. Intracellular Delivery of Anti-SMC2 Antibodies against Cancer Stem Cells. Pharmaceutics 2020, 12, 185. [CrossRef]

187. Wang, S.; Ren, W.; Wang, J.; Jiang, Z.; Saeed, M.; Zhang, L.; Li, A.; Wu, A. Black TiO2-based nanoprobes for T1-weighted MRI-guided photothermal therapy in CD133 high expressed pancreatic cancer stem-like cells. Biomater. Sci. 2018, 6, 2209-2218. [CrossRef]

188. Huai, Y.; Zhang, Y.; Xiong, X.; Das, S.; Bhattacharya, R.; Mukherjee, P. Gold Nanoparticles sensitize pancreatic cancer cells to gemcitabine. Cell Stress. 2019, 3, 267-279. [CrossRef] [PubMed] 
189. Khan, S.; Setua, S.; Kumari, S.; Dan, N.; Massey, A.; Hafeez, B.B.; Yallapu, M.M.; Stiles, Z.E.; Alabkaa, A.; Yue, J.; et al. Superparamagnetic iron oxide nanoparticles of curcumin enhance gemcitabine therapeutic response in pancreatic cancer. Biomaterials 2019, 208, 83-97. [CrossRef] [PubMed]

190. Marengo, A.; Forciniti, S.; Dando, I.; Dalla Pozza, E.; Stella, B.; Tsapis, N.; Yagoubi, N.; Fanelli, G.; Fattal, E.; Heeschen, C.; et al. Pancreatic cancer stem cell proliferation is strongly inhibited by diethyldithiocarbamate-copper complex loaded into hyaluronic acid decorated liposomes. Biochim. Biophys. Acta. Gen. Subj. 2019, 1863, 61-72. [CrossRef] [PubMed]

191. Azmi, A.S.; Khan, H.Y.; Muqbil, I.; Aboukameel, A.; Neggers, J.E.; Daelemans, D.; Mahipal, A.; Dyson, G.; Kamgar, M.; Al-Hallak, M.N.; et al. Preclinical Assessment with Clinical Validation of Selinexor with Gemcitabine and Nab-Paclitaxel for the Treatment of Pancreatic Ductal Adenocarcinoma. Clin. Cancer Res. J. Am. Assoc. Cancer Res. 2020, 26, 1338-1348. [CrossRef] [PubMed] 